\title{
EXTRACTION OF ARABINOXYLANS FROM WHEAT BRAN USING HYDROTHERMAL PROCESSES ASSISTED BY HETEROGENEOUS CATALYSTS
}

\author{
Nuria Sánchez-Bastardo, Alberto Romero, Esther Alonso* \\ *Corresponding author: High Pressure Processes Group - Chemical Engineering and \\ Environmental Technology Department, C/Dr. Mergelina S/N, University of Valladolid, 47011, \\ Spain, +349834231 75, ealonso@iq.uva.es
}

\begin{abstract}
The extraction/hydrolysis process of arabinoxylans from destarched wheat bran was studied in this work using different mesoporous silica supports and the corresponding $\mathrm{RuCl}_{3}$-based catalysts. The effects of temperature, time, catalyst supports and ruthenium catalysts were investigated and discussed in terms of the arabinoxylans extraction yield and their polymerization degree. Relatively high temperatures $\left(180^{\circ} \mathrm{C}\right)$, short extraction times $(10$ minutes) and $\mathrm{RuCl}_{3}$ supported on $\mathrm{Al}-\mathrm{MCM}-48$ led to a high amount of arabinoxylans extracted (78\%) with a low molecular weight $(9 \mathrm{KDa})$. Finally, a relation between the operating conditions, the arabinoxylans extraction yield and the molecular weight was stablished based on the obtained results.
\end{abstract}

Abbreviation: AXs, arabinoxylans; DWB, destarched wheat bran

Keywords: Hemicelluloses fractionation, wheat bran, arabinoxylans, heterogeneous catalysis, hydrothermal process, biomass

\section{Chemical compounds studied in this article}

Xylose (PubChem CID: 135191); Arabinose (PubChem CID: 439195) 


\section{Highlights:}

- Effects of ruthenium catalyst, temperature, time and catalyst support are discussed

- $\mathrm{RuCl}_{3}$-based catalysts show good activity for the arabinoxylans extraction from wheat bran

- Liquid extracts are characterized in terms of sugars, molecular weight and purity

\section{Introduction}

The conversion of biomass within biorefineries into chemicals, materials, energy and specialty products is seen as a real possibility for the substitution of fossil resources. Fossil fuels are currently the most used energy source, but their depletion and non-renewal are forcing to look for other suitable feedstocks (Amidon \& Liu, 2009; Apprich et al., 2014; Tathod \& Dhepe, 2015). Biomass is nowadays produced in huge amount all over the world. Around $95 \%$ of this biomass is as lignocellulosic material that is not edible for humans, what makes its use attractive for the production of many useful platform chemicals or biofuels (Sahu \& Dhepe, 2012). In recent years, lignocellulosic biomass, which is mainly formed by three components, cellulose (ca. 50\%), hemicellulose (ca. 30\%) and lignin (ca. 20\%), is considered an excellent raw material for chemicals synthesis (Tathod \& Dhepe, 2015). Cellulose is a long chain polysaccharide represented by the general formula $\left(\mathrm{C}_{6} \mathrm{H}_{10} \mathrm{O}_{5}\right)_{n}$ ( $n$ represents the number of glucose molecules). It has a high degree of polymerization (ca. 10,000), a high molecular weight (ca. 500,000) and is composed by the $\beta-1,4$ glycosidic linkage of D-glucopyranose units. Hemicelluloses have a more complex structure and a lower degree of polymerization than cellulose. It is an amorphous heteropolysaccharide composed by a straight-chain skeleton formed mainly by xylans. This xylan structure has, at the same time, branches of D-glucopyranose, D-galactopyranose and D-mannopyranose monomers, L-arabinofuronase and D-xylopyranose monomers. Lignin is a natural and aromatic polymer where the phenylpropane units, with hydroxyl and methoxy groups, are connected basically by ether bonds (Tekin, Karagöz, \& Bektaş, 2014).

Besides wood and non-food crops, agricultural residues like straw and corn stover, as well as other by-products of several sources, are of high interest as feedstocks (Apprich et al., 2014). 
Wheat bran is a by-product of the roller milling of wheat grain and represents such a by-product, which accrues in enormous quantities during the production of white wheat flour. It is estimated that 150 million tons are produced per year worldwide and currently is mainly used as a low value ingredient in animal feed (12\% water, $13-18 \%$ protein, $3-8 \%$ ash and $56 \%$ carbohydrates) (Nandini \& Salimath, 2001; Prückler et al., 2014).

Valuable compounds (eg. starch, lactic acid, succinic acid, acetone/butanol/ethanol, furfural, HMF, arabinoxylans and $\beta$-glucans, among others) can be produced from the carbohydrate fraction of wheat bran. In particular, arabinoxylans (AXs) can be hydrolyzed into xylose and arabinose and then further hydrogenated to obtain xylitol and arabitol (Figure 1). These sugars alcohols are two of the top 12 value-added products derived from biomass included in the report published by the US Department of Energy (DOE). For example, xylitol is used in food and pharmaceutical industry as a low calorific value sweetener. Another product to be produced from xylose is furfural, which is employed in the synthesis of different solvents, lubricants, medicines and adhesives (Sahu \& Dhepe, 2012).

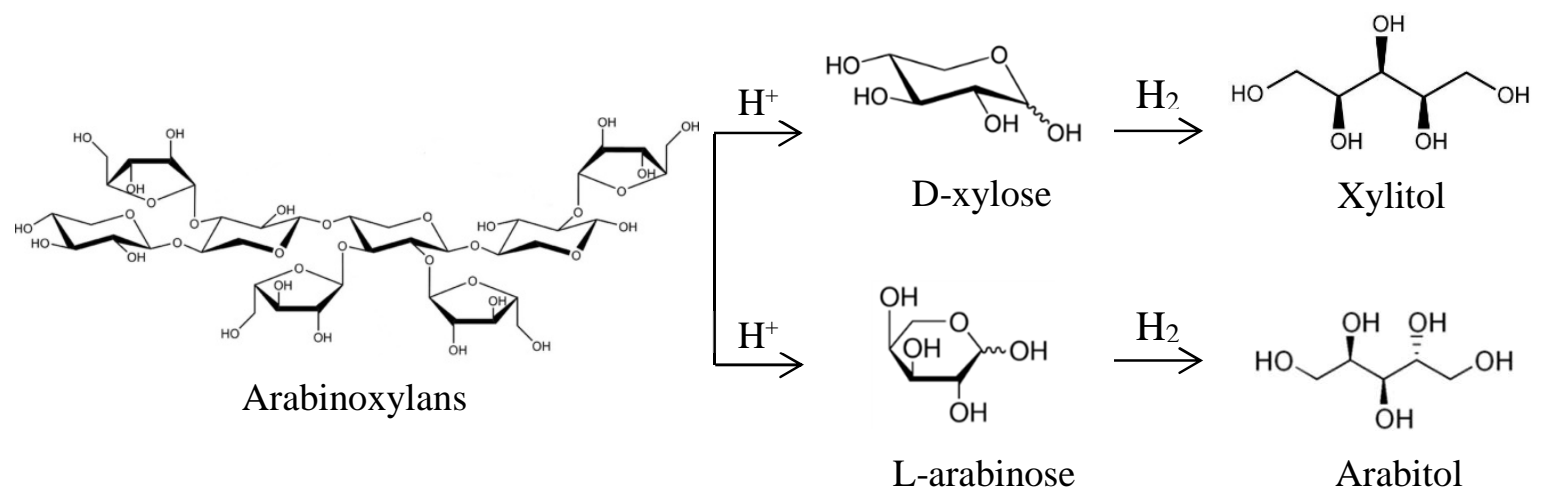

Figure 1. Conversion of arabinoxylans into sugar alcohols (Kobayashi, Tasuku Komanoya, Guha, Hara, \& Fukuoka, 2011; Tathod, Kane, Sanil \& Dhepe, 2014)

AXs belong to the hemicellulosic part of biomass and are a major structural component of cell walls of wheat bran, between 10.9 and $26.0 \%$ based on dry basis (Apprich et al., 2014). AXs are composed of a backbone of $\beta-1,4$ linked D-xylopyranosyl residues, which can be substituted at $\mathrm{C}(\mathrm{O})-2, \mathrm{C}(\mathrm{O})-3$ or both irregularly. The major substituent is single $\alpha$-L-arabinofuranose linked to 
the xylan at C(O)-1 (Apprich et al., 2014; Ordaz-Ortiz \& Saulnier, 2005; Zhang, Smith, \& Li, 2014).

AXs of cereals can be divided into two groups: water-extractable (WEAXs) and water un-extractable (WUAXs) arabinoxylans. WEAXs are weakly connected to the cell wall surface and are a minor part of the total AXs. Nevertheless, WUAXs represent the most plentiful part of the AXs and are found in the cell wall of the cereal linked to other AXs and other cell wall components through covalent and non-covalent bonds (Ganguli \& Tumer, 2008; Gebruers et al., 2008; Izydorczyk \& Biliaderis, 2007; Zhang et al., 2014). Some authors have suggested that water at relatively mild conditions (e.g. below $100^{\circ} \mathrm{C}$ ) is not able to break the cross-links between the WUAXs and the wall matrix (Izydorczyk \& Biliaderis, 2007). In order to improve the AXs extraction yield from different biomass, several techniques, such as hydrothermal treatments (Bobleter, 1994; Buranov \& Mazza, 2010; Carvalheiro, Garrote, Parajó, Pereira, \& Gírio, 2005; Dien et al., 2006; Garrote, Domínguez, \& Parajó, 1999; Garrote, Domínguez, \& Parajó, 2001; Garrote, Domínguez, \& Parajó, 2002; Kim, Hendrickson, Mosier, \& Ladisch, 2009; Lavarack, Griffin, \& Rodman, 2000; Li, Converse, \& Wyman, 2003; Maes \& Delcour, 2002; Mok \& Antal, 1992; Nabarlatz, Farriol, \& Montané, 2004; Negahdar, Delidovich, \& Palkovits, 2016; Reisinger et al., 2013; Shen \& Wyman, 2011; Tekin et al., 2014), chemical-solvent extractions (Adams et al., 1955; Aguedo, Fougnies, Dermience, \& Richel, 2014; Bataillon, Mathaly, Nunes Cardinali, \& Duchiron, 1998; Buranov \& Mazza, 2010; Choteborská et al., 2004; Doner, Chau, Fishman, \& Hicks, 1998; Höije, Gröndahl, Tømmeraas, \& Gatenholm, 2005; Hollmann \& Lindhauer, 2005; Kim, Kreke, \& Ladisch, 2013; Kusema et al., 2011; Lavarack, Griffin, \& Rodman, 2002; Maes \& Delcour, 2002; Shen \& Wyman, 2011; Swennen, Courtin, Lindemans, \& Delcour, 2006; Xu et al., 2006; Yao, Nie, Yuan, Wang, \& Qin, 2015; Zhang, Wang, Zhou, \& Fu, 2008; Zhou et al., 2010), enzymatic processes (Aguedo et al., 2014; Beaugrand et al., 2004; Beaugrand, Crônier, Debeire, \& Chabbert, 2004; DervillyPinel, Rimsten, Saulnier, Andersson, \& Aman, 2001; Dien et al., 2006; Faurot et al., 1995; Höije et al., 2005; Ogawa, Takeuchi, \& Nakamura, 2005; Ordaz-Ortiz \& Saulnier, 2005; 
Reisinger et al., 2013; Zhang, Zhou, \& Wang, 2008; Zhou et al., 2010), and mechanical-chemical methods (Aguedo, Vanderghem, Goffin, Richel, \& Paquot, 2013; Buranov \& Mazza, 2010; Ebringerova, Hromadkova, Alfoldi, \& Ibalova, 1998; Jacquemin, Zeitouna, Sablayrolles, Pontalier, \& Rigal, 2012; Josefsson, Lennholm, \& Gellerstedt, 2002; Rose \& Inglett, 2010; Sun \& Tomkinson, 2002; Sun et al., 2005; Yoshida, Tsubaki, Teramoto, \& Azuma, 2010;Zeitoun, Pontalier, Marechal, \& Rigal, 2010; Zhang et al., 2008; Zhang et al., 2014) have been studied. The advantages and disadvantages of all these methods for AXs extraction were discussed by Zhang et al. (Zhang et al., 2014). Hydrothermal treatments are performed in water under relatively high experimental conditions $\left(150-230^{\circ} \mathrm{C}\right)$ (Garrote et al., 1999). These treatments are green processes and the yields achieved with them are relatively high (58-71\%) (Dien et al., 2006; Garrote et al., 2001; Reisinger et al., 2013; Nabarlatz et al., 2004). Chemical methods using bases or acids are not environmentally-friendly and the separation process at the end of the extraction raises sharply the operating costs. Additionally, corrosion caused by severe acid treatments increase the equipment costs. AXs yield obtained with chemical methods is between 26\% and 57\% (Aguedo et al., 2014; Höije et al., 2005; Hollmann \& Lindhauer, 2005). Enzymatic extractions are green processes and they get good extraction yields (17-91\%) (Aguedo et al., 2014; Beaugrand et al., 2004; Höije et al., 2005; Maes \& Delcour, 2002). However, the difficulty of recovery, the long time required, the need for a strict control of the enzymes and the high enzymes price make necessary to seek alternatives. Concerning mechanical processes, they are high efficient treatments, but their main problems are the uncontrolled degradation of AXs molecules and the harsh pressure and temperature conditions. Hydrothermal methods assisted by heterogeneous catalysts are a good alternative to overcome all these disadvantages. Although in recent years several authors have reported the use of heterogeneous acid catalysts for the conversion of cellulose (Das, Hazarika, Goswami, Yadav, \& Khound, 2016; De Almedia, De Albuquerque, Souza, \& Meneghetti, 2016; Geboers, Van de Vyver, Ooms, Op de Beeck, \& Jacobs, 2011; Hara, 2010; Hu, Li, Wu, Lin, \& Zhou, 2016; Huang \& Fu, 2013; Negahdar et al., 2016; Van de Vyver et al., 2011) not many works are found for the conversion of hemicelluloses over solid catalysts. Sahu et al. (Sahu \& 
Dhepe, 2012) reported a one-pot process catalyzed by solid acid catalysts to convert purified hemicelluloses and bagasse into C5 sugars. They achieved a yield of xylose and arabinose of $62 \%$ at $170{ }^{\circ} \mathrm{C}$ after 1 hour of extraction time using HBeta zeolite $(\mathrm{Si} / \mathrm{Al}=19)$. Kusema et al. (Kusema et al., 2011) and Salmi et al. (Salmi et al., 2014) have studied the hydrolysis of commercial arabinogalactans into monomers over homogeneous and heterogeneous catalysts but not the extraction itself from a real biomass. Catalytic processes can reduce operation times and thus products degradation and energy consumption. Moreover, the easy removal of the solid catalysts from the liquid extract allows their recovery and reutilization. In this research, the fractionation and extraction process of AXs from wheat bran has been studied using hydrothermal treatments assisted by different supports and $\mathrm{RuCl}_{3}$-based catalysts. These metal supported catalysts have been successfully tested in hemicelluloses hydrogenation reactions to obtain sugar alcohols (Faba et al., 2014; Kusema et al., 2012; Mishra, Dabbawala, \& Hwang, 2013;Murzin et al., 2014; Sifontes Herrera, Saleem, Kusema, Eränen, \& Salmi, 2012; Yadav, Mishra, \& Hwang, 2012).This means that if they are also suitable for the extraction of AXs from a solid matrix, a one-pot process for the direct conversion of biomass into sugar alcohols could be addressed.

The aim of this work is to obtain high extraction yields of low molecular weight AXs from destarched wheat bran using hydrothermal methods assisted by heterogeneous catalysts. Moreover, it is an objective of this research to demonstrate that heterogeneous acid catalysts can decouple the hemicelluloses from their solid matrix (destarched wheat bran, in this case) and convert them into a mixture of monosaccharides and soluble oligosaccharides/polysaccharides. Different experimental conditions (catalyst, temperature, time and catalyst support) were tested in order to discuss their influence on the yield and the molecular weight of the obtained AXs. 


\section{Experimental}

\subsection{Raw material}

Wheat bran was supplied by Emilio Esteban S.A., a cereal milling industry located in Valladolid (Spain) and used as raw material for all the AXs extraction experiments after a destarching pretreatment.

\subsection{Wheat bran particle size distribution}

The particle size (PS) of wheat bran was determined by screening (CISA RP.20; CISA) with different mesh size sieves $(50 \mu \mathrm{m}-2 \mathrm{~mm})$. Screening was performed for a specific time. After that, each sieve plus the amount of wheat bran held therein was weighed. This sieving process was done several times until the weight of the wheat bran retained on every sieve was constant.

\subsection{Wheat bran destarching pretreatment}

Wheat bran contains high levels of starch (13.8-24.9\%) (Apprich et al., 2014), which on the one hand, leads to viscous slurries and low purity extracts and on the other hand, hinders the consequent separation and purification processes, in the case that its removal is not performed before the hemicelluloses extraction itself. As starch can be removed easily and successfully at relatively low temperatures (Benito-Román, Alonso, Gairola, \& Cocero, 2013; Benito-Román, Alonso, Palacio, Prádanos, \& Cocero, 2014; Tirpanalan, Reisinger, Huber, Kneifel, \& Novalin, 2014), it is obvious to consider a first fractionation of this compound. That is why in this work wheat bran was first destarched before being used for the extraction experiments. This destarching process was based on those found in literature (Benito-Román et al., 2013; Benito-Román et al., 2014; Tirpanalan et al., 2014). It consisted of suspending 20 grams of wheat bran in $400 \mathrm{~mL}$ of a phosphate buffer (pH 5-6). This suspension was gently stirred for 1 hour at $65^{\circ} \mathrm{C}$ using $1.0 \mathrm{~mL}$ of $\alpha$-amylase (Fungamyl® $800 \mathrm{~L}$; Novozymes) in order to remove the major part of the starch before the extraction. Then the destarched wheat bran (DWB) was rinsed thoroughly several times. Finally, this solid was frozen at $-4{ }^{\circ} \mathrm{C}$ overnight and freeze dried (LyoQuest; Telstar) for 2 days to eliminate all the water content. 


\subsection{Destarched wheat bran characterization}

The composition of the DWB was determined according to the Laboratory Analytical Procedure (LAP) for biomass analysis provided by the National Renewable Energy Laboratory (Sluiter \& Sluiter, 2011). The composition was determined in the destarched wheat bran. The sample was subjected to two consecutive Soxhlet extractions for 24 hours each using water and ethanol as solvents, respectively, in order to remove the extractives. These extractives are but not limited to inorganic matter, non-structural sugars, nitrogenous material, chlorophyll, waxes and other minor components. For the determination of structural carbohydrates and lignin, $300 \mathrm{mg}$ of a solid sample (with extractives) were weighed and $3 \mathrm{~mL}$ of sulfuric acid (72\%) were added while stirring. This mixture was incubated in a thermostatic bath at $30^{\circ} \mathrm{C}$ for 1 hour and stirred every 5-10 minutes. After the incubation, $84 \mathrm{~mL}$ of milli-Q water were added and the sample was autoclaved at $121^{\circ} \mathrm{C}$ for 1 hour using the liquid settings. The final product was allowed slowly cool to room temperature and then vacuum filtered and rinsed thoroughly. A liquid aliquot of $50 \mathrm{~mL}$ was used to determine the soluble lignin and the carbohydrates. The remaining solid was collected to analyze the content in insoluble lignin. To determine the soluble lignin, the absorbance of the liquid aliquot was measured at $280 \mathrm{~nm}$ with an UV-Visible spectrophotometer. The extinction coefficient for wheat bran had a value of $18.675 \mathrm{~L} \mathrm{~g}^{-1} \mathrm{~cm}^{-1}$ according to literature (Fukushima \& Hatfield, 2004). In order to know the carbohydrates composition, a similar liquid aliquot was neutralized with calcium carbonate to a $\mathrm{pH}$ between 5 and 6. The sample was filtered and carbohydrates (glucose, xylose, arabinose, galactose and mannose) were identified and quantified by HPLC. The solid resultant from the filtration was dried at $105^{\circ} \mathrm{C}$ for 24 hours and weighed. Finally, the dried solid was placed in a muffle at $575^{\circ} \mathrm{C}$ and weighed again. The difference between the dry and the calcined solid corresponds with the amount of insoluble lignin. The protein content in the DWB was determined following a standardized Kjeldahl method (Hames, Scarlata, \& Sluiter, 2008) using a nitrogen to protein conversion factor of 5.7 applicable to wheat bran (Hames et al., 2008; Maes \& Delcour, 2002; Seyer \& Gélinas, 2009). For the ash content, a certain amount of the sample was calcined at $575^{\circ} \mathrm{C}$ until constant weight. The part of the sample which was not burned corresponded to the 
ash. Finally, the starch remained in the wheat bran after the destarching pretreatment was quantified using an assay kit (Total Starch Assay Procedure, Method a); Megazyme International Ltd.).

\subsection{Support and catalyst preparation}

Synthesis of mesoporous silica MCM-48 and Al-MCM-48 was carried out using the hydrothermal procedure described by Alberto Romero et al. (Romero, Alonso, Sastre, \& NietoMárquez, 2016). First, n-hexadecyltrimethylammonium bromide was dissolved in a solution formed by $42 \mathrm{~mL}$ of distilled water, $18 \mathrm{~mL}$ of absolute ethanol and $13 \mathrm{~mL}$ of aqueous ammonia (20\%) by stirring for 15 minutes; $0.077 \mathrm{~g}$ of sodium aluminate were incorporated only in the case of the Al-MCM-48 preparation; and then $4 \mathrm{~mL}$ of tetraethyl orthosilicate were added dropwise. This solution was further stirred for $18 \mathrm{~h}$. A white precipitate was then collected by filtration and washed with distilled water. This precipitate was dried at $60{ }^{\circ} \mathrm{C}$ overnight. Dried samples were calcined from 80 to $550{ }^{\circ} \mathrm{C}$ with a heating rate of $2{ }^{\circ} \mathrm{C} / \mathrm{min}$ and maintained at $550^{\circ} \mathrm{C}$ overnight.

Ruthenium catalysts were prepared by the wetness impregnation (WI) method using the so prepared MCM-48 or Al/MCM-48 as supports. The ruthenium precursor (ruthenium (III) chloride anhydrous; Strem Chemicals Inc.) and the corresponding support were suspended in water and sonicated for 10 minutes. The suspension containing the ruthenium precursor and the support were mixed and heated up with a rate of $1{ }^{\circ} \mathrm{C} / \mathrm{min}$ from $30^{\circ} \mathrm{C}$ to $80^{\circ} \mathrm{C}$. The impregnation finished when the water was completely evaporated. The catalyst was then dried overnight at $105^{\circ} \mathrm{C}$.

\subsection{Support and catalyst characterization}

Nitrogen adsorption-desorption isotherms were performed with ASAP 2020 (Micromeritics, USA) to obtain surface and pore properties of the catalytic materials. Prior to analysis, the samples were outgassed overnight at $350{ }^{\circ} \mathrm{C}$. Total specific surface areas were determined by the multipoint BET method at $P / P_{0} \leq 0.3$, while total specific 
pore volumes were evaluated from $\mathrm{N}_{2}$ uptake at $P / P_{0} \geq 0.99$. Pore diameter was obtained by BJH adsorption average $\left(4 \cdot \mathrm{V} \cdot \mathrm{A}^{-1}, \mathrm{~nm}\right)$.

The metal loading of the $\mathrm{RuCl}_{3}$-based catalysts was determined by atomic absorption (AA) spectrophotometry (SPECTRA 220FS analyser) after an acid digestion of the samples (Romero et al., 2016).

The particle size distribution of the mesoporous supports and the ruthenium catalysts was measured by Light Scattering (Malvern Mastersizer 2000; Malvern Instruments).

The acidity of the different supports and metal catalysts was estimated by titration with $\mathrm{NaOH}$. This method is based on the reported by several authors (Hu et al., 2015; Hu et al., 2016; Liu, Tian, Jiang, \& Yu, 2013; Wang et al., 2011; Zheng, Chen, Hu, Yan, \& Kong, 2014).

\subsection{Arabinoxylans extraction experiments}

All the experiments were carried out in an AISI 304 stainless steel vessel $(170 \mathrm{~mL})$. The extractor was heated by an electric heater $(275 \mathrm{~W})$ placed around the wall and the temperature was controlled by a PID controller (ICP, TC21). A pressure gauge $0-25$ bar was used to measure the autogeneous pressure inside the reactor. The DWB suspension was stirred continuously during the process with a magnetic stirrer at a constant rotational speed of $300 \mathrm{rpm}$. The typical experimental procedure was carried out introducing $160 \mathrm{~mL}$ of the DWB suspension $\left[30 \mathrm{~g} \cdot \mathrm{L}^{-1}\right]$ in the reactor. Then the ruthenium catalyst was added and this mixture was stirred at $600 \mathrm{rpm}$ for 5 minutes before the reactor was closed and the temperature set. As other authors have considered before (Morais, Matuchaki, Andreaus, \& Bogel-Lukasik, 2016; Sahu \& Dhepe, 2012), the starting time $(0 \mathrm{~min})$ of the extraction was taken when the set temperature was reached. At the end of the experiments, the reactor was cooled down with a dry ice bath. The slurries were centrifuged for $10 \mathrm{~min}$ at $7800 \mathrm{rpm}$ (SIGMA 2-16P; SIGMA) and then vacuum filtered. The liquid was used for further analyses of free and total sugars, degradation products and by-products. 


\subsection{Products analysis}

The identification and quantification of sugars and degradation products were done by High Performance Liquid Chromatography (HPLC). The amount of sugars as monomers and oligomers was also determined. The monosaccharides and the degradation products were directly analyzed in the liquid sample after the extraction. However, total sugars were measured according to the Laboratory Analytical Procedure (LAP) written by the NREL (Sluiter et al., 2008). Briefly, this method consisted of adding $0.8 \mathrm{~mL}$ of sulfuric acid (72\%) to $20 \mathrm{~mL}$ liquid aliquot and autoclave the sample at $121^{\circ} \mathrm{C}$ for 1 hour using the liquid settings. When the sample reached room temperature, calcium carbonate was added to get a $\mathrm{pH}$ between 5 and 6 . Then an aliquot of $10 \mathrm{~mL}$ was filtered (Pore size $0.22 \mu \mathrm{m}$, Diameter $25 \mathrm{~mm}$, Nylon; FILTER-LAB) and stirred together with 1 gram of mixed bed ion exchange resin (Dowex ${ }^{\circledR}$ Monosphere ${ }^{\circledR}$ MR-450 UPW hydrogen and hydroxide form matrix tyrene-divinylbenzene; Sigma-Aldrich) for 20 minutes in order to remove all the possible ions present in the sample so as not to damage the HPLC column. All the samples were analyzed using a chromatography system that consists of an isocratic pump (Waters 1515; Waters Corporation), an automatic injector (Waters 717; Waters Corporation), the appropriate HPLC columns and two detectors: IR (Waters 2414; Waters Corporation) and UV-Vis (Waters 2487; Waters Corporation). Two different HPLC columns were used for the identification and quantification of the different products in the liquid samples: 1) Supelcogel $\mathrm{Pb}$ (Supelco) for sugars (milli-Q water as mobile phase, $0.5 \mathrm{~mL} \mathrm{~min}{ }^{-1}$ as flow rate and $85^{\circ} \mathrm{C}$ as temperature) and 2) Sugar SH-1011 (Shodex) for degradation products (sulfuric acid $0.01 \mathrm{~N}$ as mobile phase, $0.8 \mathrm{~mL} \mathrm{~min}{ }^{-1}$ as flow rate and $50{ }^{\circ} \mathrm{C}$ as temperature). All the sugars and acids were identified using a Waters IR detector 2414. 5hidroxymethylfurfural (5-HMF) and furfural were determined with an UV-Vis detector at a wavelength of $254 \mathrm{~nm}$. The standards employed for the analysis HPLC were: cellobiose (98\%), glucose $(99 \%)$, xylose $(99 \%)$, rhamnose $(99 \%)$, galactose (99\%), arabinose (99\%), mannose (99\%), fructose (99\%), glyceraldehyde (95\%), glycolaldehyde (99\%), lactic acid (85\%), formic acid (98\%), acetic acid (99\%), levulinic acid (98\%), levulinic acid (98\%), acrylic acid (99\%), 
pyruvaldehyde (40\%), 5-hydroxymethilfurfural (99\%), furfural (99\%) and erythrose (75\%). All these chemicals were purchased from Sigma Aldrich (Spain) and used as received.

The molecular weight of the hemicelluloses in the liquid extract was determined by Size Exclusion Chromatography (HPLC-SEC) using the same chromatography system described before. A GPC column (SB-804 HQ; Shodex) protected by a guard column (SB-G; Shodex) and a IR detector (Waters 2414; Waters Corporation) were used for the determination of the molecular weight of the hemicelluloses extracted. The column was kept at $35{ }^{\circ} \mathrm{C}$ and the flow rate of the mobile phase $\left(\mathrm{NaNO}_{3} 0.1 \mathrm{M}+\mathrm{NaN}_{3} 0.02 \%\right.$ in milli-Q water) was set at $0.5 \mathrm{~mL} \mathrm{~min}^{-1}$. A set of eight different pullulans standards (STANDARD P-82; Shodex) ranged between 6.1 and $642 \mathrm{KDa}$ of average molecular weight $(\mathrm{Mw})$ were dissolved in milli-Q water and used to obtain the corresponding calibration curve. Chromatograms were processed by means of the Breeze Software (Waters Corporation). The molecular weight distribution was given in terms of the weight average $(\mathrm{Mw})$ and the number average $(\mathrm{Mn})$ molecular weight; likewise, the polydispersity index $(\mathrm{Mw} / \mathrm{Mn})$ was calculated by this software.

The purity of the liquid extract was measured in terms of its carbon content, which was determined by Total Organic Carbon (TOC) analysis using a Shimadzu TOC-VCSH equipment. The oligomer AXs yield (\%) and the total AXs yield (\%) were calculated as follows:

$$
\begin{gathered}
\% \mathrm{~A}+\mathrm{X} \text { monomeric yield }=\frac{(\mathrm{A}+\mathrm{X}) \text { as monomeric sugars in liquid extract }(\mathrm{g})}{(\mathrm{A}+\mathrm{X}) \text { in raw material }(\mathrm{g})} \times 100 \\
\% \mathrm{AX} \text { total yield }=\frac{(\mathrm{A}+\mathrm{X}) \text { as monomeric and oligomeric sugars in liquid extract }(\mathrm{g})}{(\mathrm{A}+\mathrm{X}) \text { in raw material }(\mathrm{g})} \times 100
\end{gathered}
$$

$\%$ Liquid extract purity $=\frac{\text { carbon content of }(\mathrm{A}+\mathrm{X}) \text { as monomeric and oligomeric sugars in liquid extract }(\mathrm{g})}{\text { total carbon content in liquid extract given by TOC }(\mathrm{g})} \times 100$ 


\section{Results and discussion}

\subsection{Raw material characterization}

Chemical composition of DWB and its particle size distribution can be seen in Table 1. The hemicelluloses content was $38.0 \%$ with a ratio arabinose/xylose of 0.53 . The amount of xylose and arabinose in the DWB is $26.2 \%$ and $13.8 \%$ on dry basis, respectively.

Most particles (64.1 wt $\%$ ) are in the range between 2.00 and $1.00 \mathrm{~mm} .17 .1 \mathrm{wt} \%$ of the particles are found between $1.00 \mathrm{~mm}$ and $500 \mu \mathrm{m}$ and $14.4 \mathrm{wt} \%$ have a particle size higher than 2.00 $\mathrm{mm}$. The amount of particles under $500 \mu \mathrm{m}$ is very small.

Table 1. Chemical composition of destarched wheat bran (\% dry basis) and particle size distribution

a) Chemical composition

\begin{tabular}{|c|c|c|c|c|c|c|c|}
\hline Component & Cellulose & Hemicelluloses & Soluble lignin & Insoluble lignin & Starch & Protein & Ash \\
\hline $\mathrm{g} / 100 \mathrm{~g}$ DWB & $15.3 \pm 0.4$ & $38.0 \pm 2.1$ & $21.5 \pm 0.4$ & $4.9 \pm 1.3$ & $2.1 \pm 0.3$ & $14.5 \pm 0.5$ & $3.2 \pm 0.1$ \\
\hline
\end{tabular}

b) Sugar composition

\begin{tabular}{llllll}
\hline Component & Glucose & Xylose & Galactose & Arabinose & Mannose \\
\hline g/100g DWB & $19.1 \pm 0.5$ & $26.2 \pm 1.6$ & $2.2 \pm 0.2$ & $13.8 \pm 0.4$ & $0.9 \pm 0.3$ \\
\hline
\end{tabular}

c) Particle size distribution

\begin{tabular}{ll}
\hline Particle size (PS) & wt $\%$ \\
\hline PS $\geq 2.00 \mathrm{~mm}$ & 14.4 \\
$2.00 \mathrm{~mm}>$ PS $\geq 1.00 \mathrm{~mm}$ & 64.1 \\
$1.00 \mathrm{~mm}>$ PS $\geq 500 \mu \mathrm{m}$ & 17.0 \\
$500 \mu \mathrm{m}>$ PS $\geq 250 \mu \mathrm{m}$ & 3.5 \\
$250 \mu \mathrm{m}>$ PS $\geq 100 \mu \mathrm{m}$ & 1.0 \\
$100 \mu \mathrm{m}>$ PS $\geq 50 \mu \mathrm{m}$ & 0.0 \\
PS $<50 \mu \mathrm{m}$ & 0.0 \\
\hline
\end{tabular}

\subsection{Catalyst characterization}

The properties of the different catalysts used in this work are summarized in Table 2.

The specific surface area, total pore volume, pore diameter and acidity values from acid-base titration of the supports and the catalysts, are presented in Table 2. Specific surface areas of 
$1298 \mathrm{~m}^{2} \cdot \mathrm{g}^{-1}$ and $1352 \mathrm{~m}^{2} \cdot \mathrm{g}^{-1}$ were obtained, while pore volumes of $0.87 \mathrm{~cm}^{3} \cdot \mathrm{g}^{-1}$ and $0.81 \mathrm{~cm}^{3} \cdot \mathrm{g}^{-}$ ${ }^{1}$ were achieved for MCM-48 and Al-MCM-48, respectively. According to these results, no significantly changes in BET surface and pore volume were detected in Al-MCM-48 compared to MCM-48. Comparing pore diameters of both supports, a slight increase in the pore diameter from $2.2 \mathrm{~nm}$ to $2.5 \mathrm{~nm}$ was observed after the introduction of Aluminum into the walls of the MCM-48. A decrease in the specific surface area and pore volume of $\mathrm{RuCl}_{3} / \mathrm{MCM}-48$ and $\mathrm{RuCl}_{3} / \mathrm{Al}-\mathrm{MCM}-48$ are noticed after the deposition of the active metal, from 1298 to $1032 \mathrm{~m}^{2} \cdot \mathrm{g}^{-}$ ${ }^{1}$ and from 1352 to $1017 \mathrm{~m}^{2} \cdot \mathrm{g}^{-1}$, respectively. This fact can be attributed to the partial blocking of the porous network of both supports. After deposition of ruthenium, no changes in terms of pore size were observed in the case of $\mathrm{RuCl}_{3} / \mathrm{MCM}-48$. However, pore size slightly increased from 2.5 to $2.7 \mathrm{~nm}$ in the case of $\mathrm{RuCl}_{3} / \mathrm{Al}-\mathrm{MCM}-48$. This fact is indicative of slender modifications of the pore structure, suggesting a higher pore blocking than in the case of $\mathrm{RuCl}_{3} / \mathrm{MCM}-48$. The ruthenium content for $\mathrm{RuCl}_{3} / \mathrm{MCM}-48$ and $\mathrm{RuCl}_{3} / \mathrm{Al}-\mathrm{MCM}-48$ was around $4 \%$ in both cases, determined by AA.

The particle size distribution of the catalysts is shown in Table 2. The different values given $(d(0.1), d(0.5)$ and $d(0.9))$ correspond to the particle size under which $10 \%, 50 \%$ and $90 \%$ of the particles are found.

Acidity is a key parameter of solid acid catalysts when they are used in extraction/hydrolysis processes. Mineral acids, such as $\mathrm{H}_{2} \mathrm{SO}_{4}$ or $\mathrm{HCl}$, are commonly used for this kind of treatments and they can achieve high yields and conversion of hemicelluloses into monosaccharides. However, as mentioned before, the obvious disadvantages of homogenous acids make authors seek solid acid catalysts with an acidity comparable with the one of mineral acids. The acidity of the catalysts used here is as follows: MCM-48 $<\mathrm{Al}-\mathrm{MCM}-48<\mathrm{RuCl}_{3} / \mathrm{MCM}-48<\mathrm{RuCl}_{3} / \mathrm{Al}-$ MCM-48. 
Table 2. Characterization of supports and $\mathrm{RuCl}_{3}$-based catalysts

\begin{tabular}{lllllllll}
\hline Catalyst & $\begin{array}{l}\mathrm{Ru} \\
(\%)\end{array}$ & $\begin{array}{l}\mathrm{S}_{\mathrm{BET}} \\
\left(\mathrm{m}^{2} \cdot \mathrm{g}^{-1}\right)\end{array}$ & $\begin{array}{l}\mathrm{V}_{\mathrm{p}} \\
\left(\mathrm{cm}^{3} \cdot \mathrm{g}^{-1}\right)\end{array}$ & $\begin{array}{l}\emptyset_{\mathrm{p}} \\
(\mathrm{nm})\end{array}$ & $\begin{array}{l}\text { Acidity } \\
(\mathrm{mEq} \mathrm{H} \cdot \mathrm{g} \text { cat. })\end{array}$ & $\begin{array}{l}\mathrm{d}(0.1) \\
(\mu \mathrm{m})\end{array}$ & $\begin{array}{l}\mathrm{d}(0.5) \\
(\mu \mathrm{m})\end{array}$ & $\begin{array}{l}\mathrm{d}(0.9) \\
(\mu \mathrm{m})\end{array}$ \\
\hline $\mathrm{MCM}-48$ & - & 1298 & 0.87 & 2.2 & 0.293 & 8.77 & 112.19 & 558.29 \\
$\mathrm{Al}-\mathrm{MCM}-48$ & - & 1352 & 0.81 & 2.5 & 0.598 & 5.40 & 86.25 & 346.49 \\
$\mathrm{RuCl}_{3} / \mathrm{MCM}-48$ & 4 & 1032 & 0.63 & 2.2 & 0.738 & 3.29 & 47.75 & 271.70 \\
$\mathrm{RuCl}_{3} / \mathrm{Al}-\mathrm{MCM}-48$ & 4 & 1017 & 0.63 & 2.7 & 1.130 & 2.68 & 48.02 & 165.94 \\
\hline
\end{tabular}

\subsection{Arabinoxylans extraction experiments}

The effect of several parameters (catalyst, temperature, time and catalyst support) was evaluated in the extraction process of AXs from destarched wheat bran in terms of arabinose + xylose as monomers and as total sugars (arabinose + xylose as monomers and oligomers). The purity of the liquid extract in AXs and its molecular weight were also taken into account and discussed.

a) Effect of Ruthenium catalyst

As shown in Figure 2, the effect of the MCM-48 support and the $\mathrm{RuCl}_{3} / \mathrm{MCM}-48$ catalyst, in the presence of water, was evaluated in the AXs extraction process. Experimental conditions for this study were $160{ }^{\circ} \mathrm{C}$ and 10 minutes. When no mesoporous silica support or ruthenium catalyst was incorporated to the extraction, the monomeric yield (4\%) and the total AXs yield (13\%) were both low. In the absence of any catalyst, the formation of this small amount of soluble oligomers may be due to the thermal hydrolysis of hemicelluloses (Sahu \& Dhepe, 2012). At high temperatures, the amount of protons derived from water is higher than at room temperature. This is represented by the $\mathrm{pK}_{\mathrm{w}}$ value of water, which is 13.99 and 11.64 at $25^{\circ} \mathrm{C}$ and $150{ }^{\circ} \mathrm{C}$, respectively (Bandura \& Lvov, 2006). The lower the $\mathrm{pK}_{\mathrm{w}}$ value of water is, the higher quantity of $\mathrm{H}_{3} \mathrm{O}^{+}$produced from water. Nevertheless, as Figure 2 displays, the use of a catalyst is required to achieve higher hemicelluloses yields. The total AXs yield was improved by MCM-48 (24\%) and even more by means of $\mathrm{RuCl}_{3} / \mathrm{MCM}-48(32 \%)$. This is in agreement with the acidity values for MCM-48 and $\mathrm{RuCl}_{3} / \mathrm{MCM}-48$. This value for $\mathrm{RuCl}_{3} / \mathrm{MCM}-48$ is 2.5 times higher than for MCM-48. MCM-48 acidity corresponds to weak acid sites due to the terminal silanol $(\mathrm{Si}-\mathrm{OH})$ groups found in this support (Xue, Lu, Guo, Wang, \& Guo, 2004). The higher acidity of the $\mathrm{RuCl}_{3} / \mathrm{MCM}-48$ compared to the MCM-48 may be related to the high 
acidity of the catalyst precursor $\left(\mathrm{RuCl}_{3}\right)$ used for the synthesis (Guisnet et al., 1993). The monomers formed were basically the same in the blank extraction and with the presence of MCM-48 (4\%). When $\mathrm{RuCl}_{3} / \mathrm{MCM}-48$ was added to the extraction, the amount of monomers obtained was slightly higher (7\%). Therefore, the support MCM-48 and the $\mathrm{RuCl}_{3}$-based catalyst caused a great improvement in the oligosaccharides yield, but not a remarkable one in the monosaccharides yield under these experimental conditions. It is also remarkable that the obtained extracts with these solids have a higher purity than without.

In default of any catalyst, the average molecular weight (MW) was $9 \mathrm{KDa}$, which together with a low amount of sugars solubilized, means that only side chains of the arabinoxylan structure were extracted. These side chains are characterized by a low molecular weight and a large amount of arabinose compared to xylose, what is in accordance with the high ratio arabinose/xylose (0.92) found in the liquid extract. Hydrolysis of side chains of hemicelluloses is preferential compared to the backbone hydrolysis due to their easier access. This results in a greater release of arabinose belonging to the side chains than of xylose from the backbone (high ratio arabinose/xylose) when the operating conditions are not strong enough. In addition to this, faster hydrolysis of side chains can be also explained by the type of bonding. Side chains are linked by $\alpha$-glycosidic bonds, whereas the different units of the xylan backbone are connected by means of $\beta$-glycosidic bonds. The easier hydrolysis of $\alpha$-glycosidic bonds than of $\beta$ glycosidic linkages also explains the faster release of side chains than units from the backbone. This is well reported by Negahdar et al. (Negahdar et al., 2016). However, the incorporation of MCM-48 or $\mathrm{RuCl}_{3} / \mathrm{MCM}-48$ led to higher amount of extracted hemicelluloses and oligomers in the liquid extracts with higher MW. At $160^{\circ} \mathrm{C}$, these two acid solids promoted the solubilization of not only side chains of AXs, but also part of the xylan backbone, resulting in a lower ratio arabinose/xylose (0.65-0.78).

In conclusion, at $160{ }^{\circ} \mathrm{C}$ and 10 minutes of extraction time, in the absence of any catalyst only side chains of AXs were obtained; however, when MCM-48 or $\mathrm{RuCl}_{3} / \mathrm{MCM}-48$ were employed, part of the xylan backbone with a relatively high MW was also extracted. 


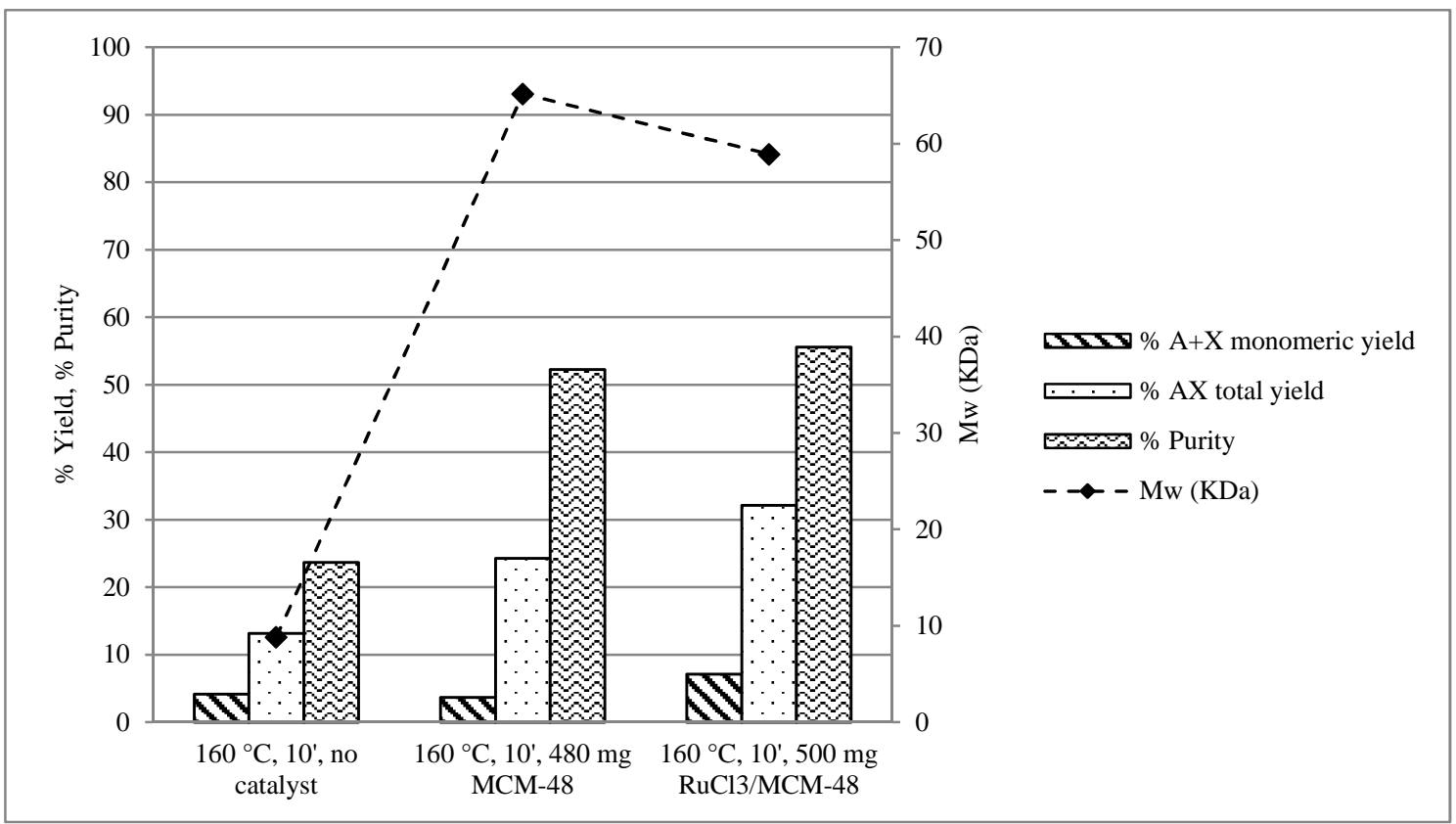

Figure 2. Effect of catalyst on the AXs yield, purity and molecular weight of the liquid extract in the AXs extraction process. Extraction conditions: $4.8 \mathrm{~g}$ of destarched wheat bran, $160 \mathrm{~mL}$ of $\mathrm{H}_{2} \mathrm{O}, 160{ }^{\circ} \mathrm{C}, 10$ minutes (A: Arabinose, X: Xylose).

b) Effect of temperature

As it has been previously discussed, $\mathrm{RuCl}_{3} / \mathrm{MCM}-48$ gave better $\mathrm{AXs}$ yield than MCM-48. This $\mathrm{RuCl}_{3}$-based catalyst was used for the study of the temperature effect. Temperature was considered between 140 and $180{ }^{\circ} \mathrm{C}$ and time was fixed at 10 minutes. Figure 3 and Table 3 contain the results arising from these experiments. Monomeric and oligomeric AXs yields (the last one calculated as the difference between total and monomeric AXs yield) increase with temperature. In this case, this growth is not due so much to the $\mathrm{pK}_{\mathrm{w}}$ value of water, as this value does not suffer a substantial change in the range $140-180{ }^{\circ} \mathrm{C}$ (Bandura \& Lvov, 2006). This improvement with temperature is explained by Arrhenius equation: the kinetic constant and therefore the reaction rate increase as temperature increases.

Molecular weight varies in the studied range. At $140{ }^{\circ} \mathrm{C}$ and $180{ }^{\circ} \mathrm{C}$, the molecular weight of the AXs extracted is in both cases around $8 \mathrm{KDa}$. The difference between these two experiments is the AXs yield and the ratio arabinose to xylose. At $140{ }^{\circ} \mathrm{C}$, the total AXs yield is quite low (12\%), but at $180{ }^{\circ} \mathrm{C}$ this yield grows up to $71 \%$. This suggests that at $140{ }^{\circ} \mathrm{C}$ only side AXs 
chains were obtained (arabinose/xylose $=0.73$ ). Nevertheless, a high AXs yield and a low MW (180 ${ }^{\circ} \mathrm{C}, 10$ minutes, $\left.\mathrm{RuCl}_{3} / \mathrm{MCM}-48\right)$ means that under these conditions part of the arabinoxylan backbone (arabinose/xylose $=0.53$ ) was solubilized and hydrolyzed into shorter oligomers. This is also in agreement with the higher amount of monomers obtained at $180{ }^{\circ} \mathrm{C}$ (13\%) than at $140{ }^{\circ} \mathrm{C}(2 \%)$. At $160{ }^{\circ} \mathrm{C}$, the total AXs yield (32\%) is found between the obtained at 140 and $180^{\circ} \mathrm{C}$. However, the molecular weight at $160^{\circ} \mathrm{C}$ is very high $(59 \mathrm{KDa})$ compared to the results derived from those two experiments (at 140 and $180{ }^{\circ} \mathrm{C}$ ). Under mild operating conditions $\left(160{ }^{\circ} \mathrm{C}, 10\right.$ minutes, $\left.\mathrm{RuCl}_{3} / \mathrm{MCM}-48\right)$, AXs solubilized in water come from side chains and from the backbone, but according to the high value of the MW, these AXs were not still as hydrolyzed as when more severe conditions $\left(180{ }^{\circ} \mathrm{C}, 10\right.$ minutes, $\left.\mathrm{RuCl}_{3} / \mathrm{MCM}-48\right)$ were applied.

In terms of purity of the liquid extract, the best temperature would correspond to $140{ }^{\circ} \mathrm{C}(62 \%)$. At $160{ }^{\circ} \mathrm{C}$ and $180{ }^{\circ} \mathrm{C}$, the purity decreases because more cellulose (Table 3 ) was found in the extract. Nonetheless, the yield was so low at $140{ }^{\circ} \mathrm{C}$ that it was decided to study the effect of time at $160^{\circ} \mathrm{C}$ and $180^{\circ} \mathrm{C}$. 


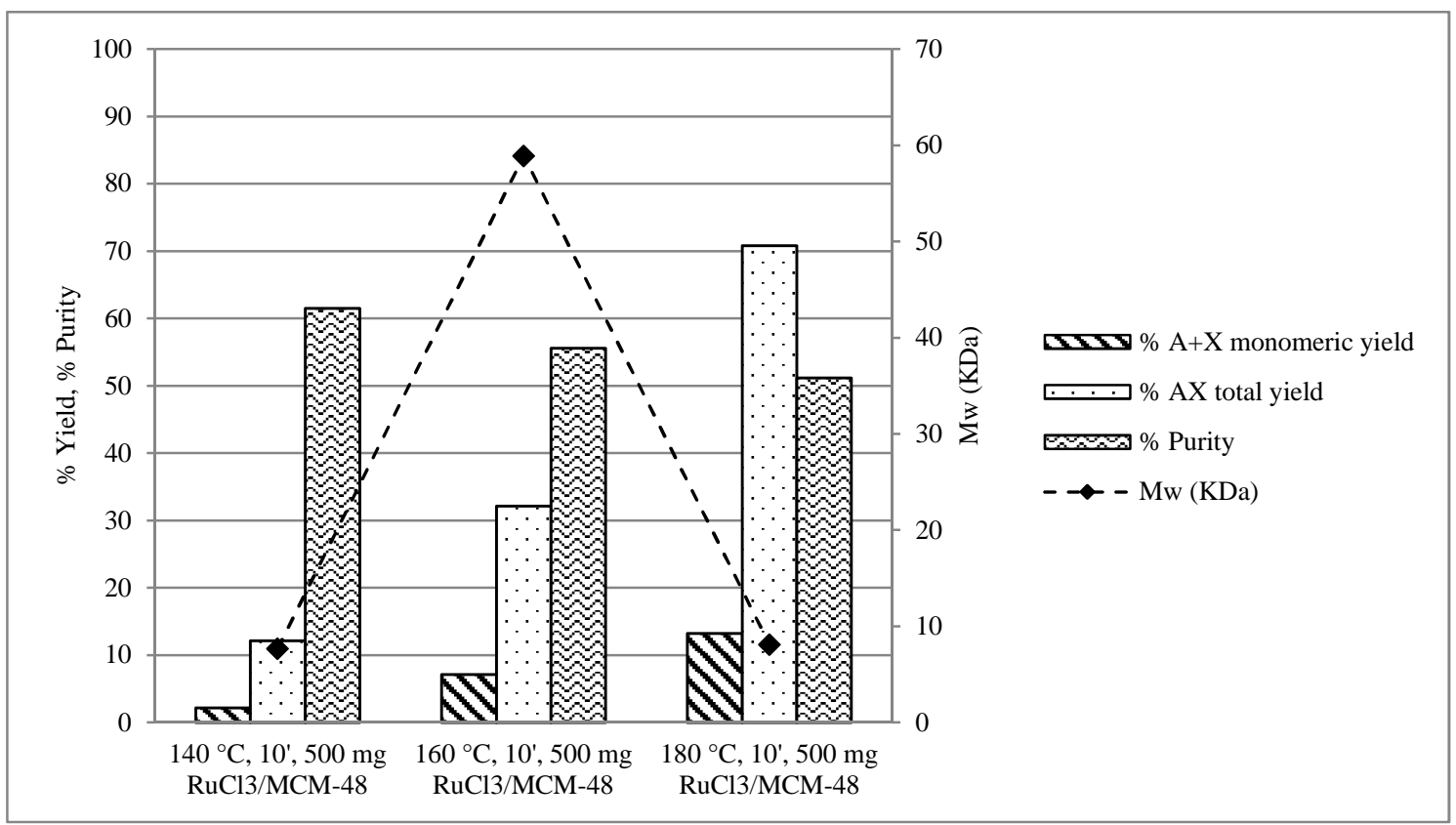

Figure 3. Effect of temperature on the AXs yield, purity and molecular weight of the liquid extract in the AXs extraction process. Extraction conditions: $4.8 \mathrm{~g}$ of destarched wheat bran, $160 \mathrm{~mL}$ of $\mathrm{H}_{2} \mathrm{O}, 10$ minutes, $500 \mathrm{mg} \mathrm{RuCl} / \mathrm{MCM}-48$ (A: Arabinose, X: Xylose).

Table 3. Effect of temperature on the yield of the different oligomer and total sugars obtained in the extraction process. Extraction conditions: $4.8 \mathrm{~g}$ of destarched wheat bran, $160 \mathrm{~mL}$ of $\mathrm{H}_{2} \mathrm{O}$, 10 minutes, $500 \mathrm{mg} \mathrm{RuCl} / 3 / \mathrm{MCM}-48$.

\begin{tabular}{|c|c|c|c|c|c|c|c|c|c|c|c|c|c|c|c|}
\hline \multicolumn{3}{|c|}{ Experimental conditions } & \multicolumn{6}{|c|}{ Yield as monomeric sugars ${ }^{\mathrm{a}}(\%)$} & \multicolumn{6}{|c|}{ Yield as total sugars ${ }^{\mathrm{b}}(\%)$} & \multirow[b]{2}{*}{$\mathrm{Ara} / \mathrm{Xyl}$} \\
\hline $\begin{array}{l}\mathrm{T} \\
\left({ }^{\circ} \mathrm{C}\right)\end{array}$ & $\begin{array}{l}\mathrm{t} \\
(\min )\end{array}$ & $\begin{array}{l}\text { Catalyst } \\
(\mathrm{mg})\end{array}$ & Glu & Xyl & Gal & Ara & Man & $\begin{array}{l}A+X \\
\text { yield }\end{array}$ & Glu & Xyl & $\mathrm{Gal}$ & Ara & Man & AX yield & \\
\hline 140 & 10 & $500 \mathrm{mg} \mathrm{RuCl} / 3 / \mathrm{MCM}-48$ & 0.2 & 0.3 & 1.8 & 5.7 & 4.2 & 2.2 & 5.8 & 10.8 & 8.0 & 14.9 & 8.4 & 12.2 & 0.73 \\
\hline 160 & 10 & $500 \mathrm{mg} \mathrm{RuCl} 3 / \mathrm{MCM}-48$ & 2.2 & 1.3 & 4.5 & 18.3 & 8.8 & 7.1 & 26.8 & 27.6 & 23.7 & 40.8 & 10.9 & 32.1 & 0.78 \\
\hline 180 & 10 & $500 \mathrm{mg} \mathrm{RuCl} 3 / \mathrm{MCM}-48$ & 2.9 & 3.0 & 10.2 & 32.8 & 14.4 & 13.3 & 28.2 & 70.6 & 46.9 & 71.2 & 14.7 & 70.8 & 0.53 \\
\hline
\end{tabular}

${ }^{a}$ Yield as monomeric sugars extracted by original sugar content in raw material

${ }^{b}$ Yield as total sugars extracted (monomeric + oligomeric) by original sugar content in raw material

${ }^{\mathrm{c}}$ Ratio arabinose/xylose as total sugars

c) Effect of time

The effect of time on the AXs extraction process has been studied at 160 (Figure 4.a) and 180 ${ }^{\circ} \mathrm{C}$ (Figure 4.b) using $\mathrm{RuCl}_{3} / \mathrm{MCM}-48$. At $160{ }^{\circ} \mathrm{C}$, the total $\mathrm{AXs}$ yield increases over time from $32 \%$ (10 minutes) to $48 \%$ (30 minutes). The arabinose + xylose monosaccharides yield follows a similar trend, rising from $7 \%$ to $11 \%$ in this time range. A clear difference between the results obtained at short (10 minutes) and longer times (20 and 30 minutes) is in the molecular weight 
of the liquid extract. As it has been said in the previous section, at $160{ }^{\circ} \mathrm{C}$ and 10 minutes using $\mathrm{RuCl}_{3} / \mathrm{MCM}-48$, the $\mathrm{AXs}$ extracted in water are derived from side chains as well as from the arabinoxylan backbone. However, they still have a relatively high molecular weight under these conditions. When longer extractions are carried out (20 and 30 minutes), not only the yield increases but also the molecular weight undergoes a drastic drop (from $59 \mathrm{KDa}$ to 19 and 13 $\mathrm{KDa}$, respectively). This implies that AXs can keep being extracted but especially they can be hydrolyzed into oligomers of low molecular weight when they are subjected to longer times. It should be noticed that the difference between the total AXs yield obtained at 20 and 30 minutes is small (44 and 48\%, respectively) and also the purity of the liquid extract starts to decline after 30 minutes, so that longer experiments have no sense.

The study at $180{ }^{\circ} \mathrm{C}$ with $\mathrm{RuCl}_{3} / \mathrm{MCM}-48$ reveals that the amount of $\mathrm{AXs}$ extracted at this temperature is much higher than at $160{ }^{\circ} \mathrm{C}$, even at short times. Experiments at 10 and 20 minutes were performed at $180{ }^{\circ} \mathrm{C}$ using $\mathrm{RuCl}_{3} / \mathrm{MCM}-48$. In both cases, the total $\mathrm{AXs}$ yield is already high ( $71 \%$ and $67 \%$, respectively). Nonetheless, the purity of the final liquid extract decreases dramatically after 20 minutes. This may be due to a higher cellulose extraction (Table 4) and a larger amount of degradation products. However, no more degradation products (acetic acid, formic acid, glycolaldehyde, 5-HMF, furfural) were detected by HPLC after 20 minutes of extraction time at $180{ }^{\circ} \mathrm{C}$. This fact is in good agreement with the results reported by Sahu et al. (Sahu \& Dhepe, 2012). The dark color resulting from the experiment at 20 minutes and $180{ }^{\circ} \mathrm{C}$ comes from the (insoluble/soluble) degradation products that cannot be detected by means of HPLC. These degradation products not identified would make the purity of the final liquid extract drop significantly. Regarding the molecular weight, although longer times let the AXs break into oligomers of shorter chains, these values are quite low after 10 (8 KDa) and 20 minutes $(4 \mathrm{KDa})$ when temperature is set at $180{ }^{\circ} \mathrm{C}$.

Results obtained at $180^{\circ} \mathrm{C}$ and 10 minutes using $\mathrm{RuCl}_{3} / \mathrm{MCM}-48$ are much better than the ones derived from the experiments at $160{ }^{\circ} \mathrm{C}$. Consequently, the next study of the influence of the catalyst support was carried out at $180^{\circ} \mathrm{C}$ and 10 minutes of extraction time. 
a) At $160^{\circ} \mathrm{C}$

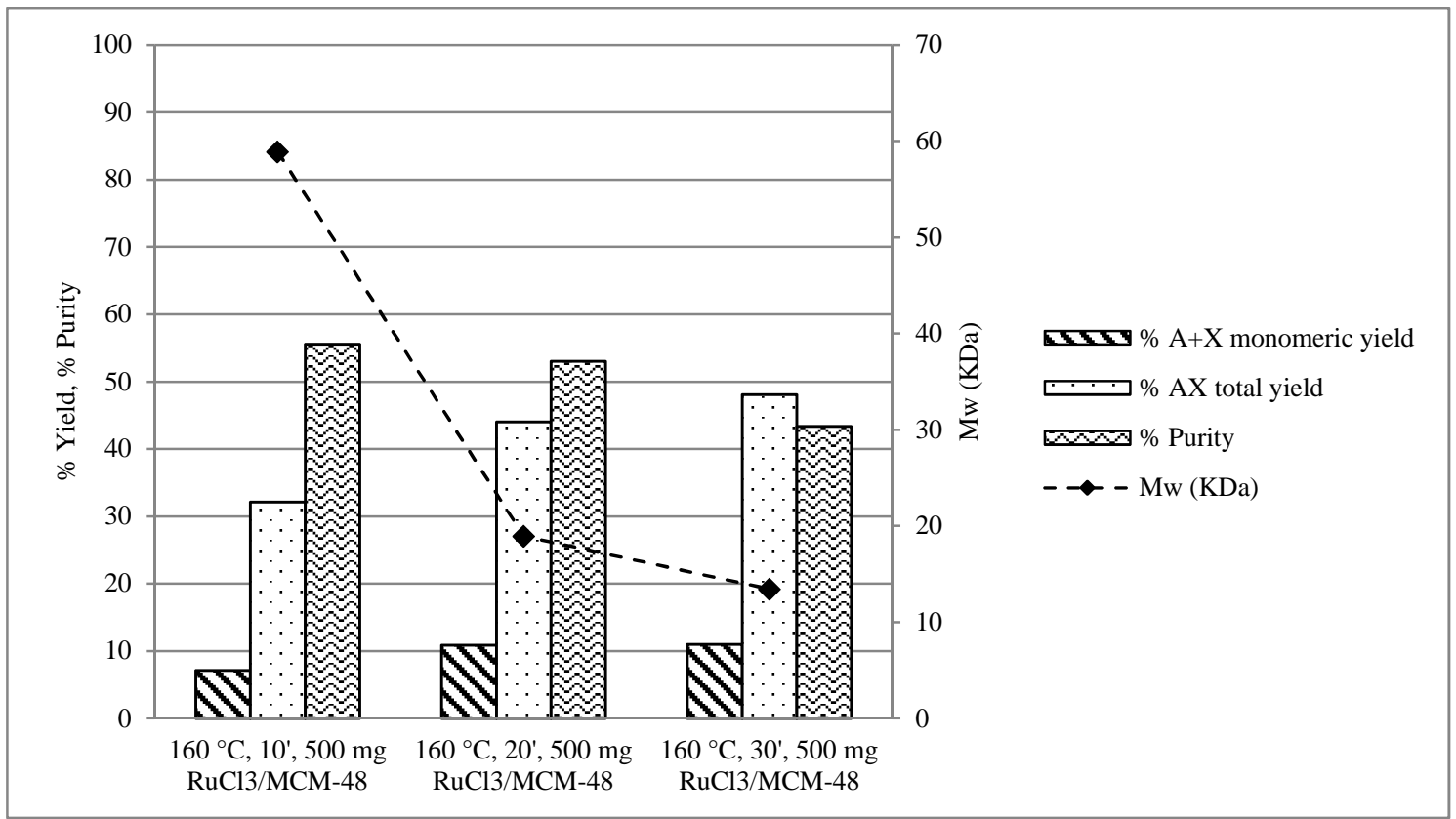

b) At $180^{\circ} \mathrm{C}$

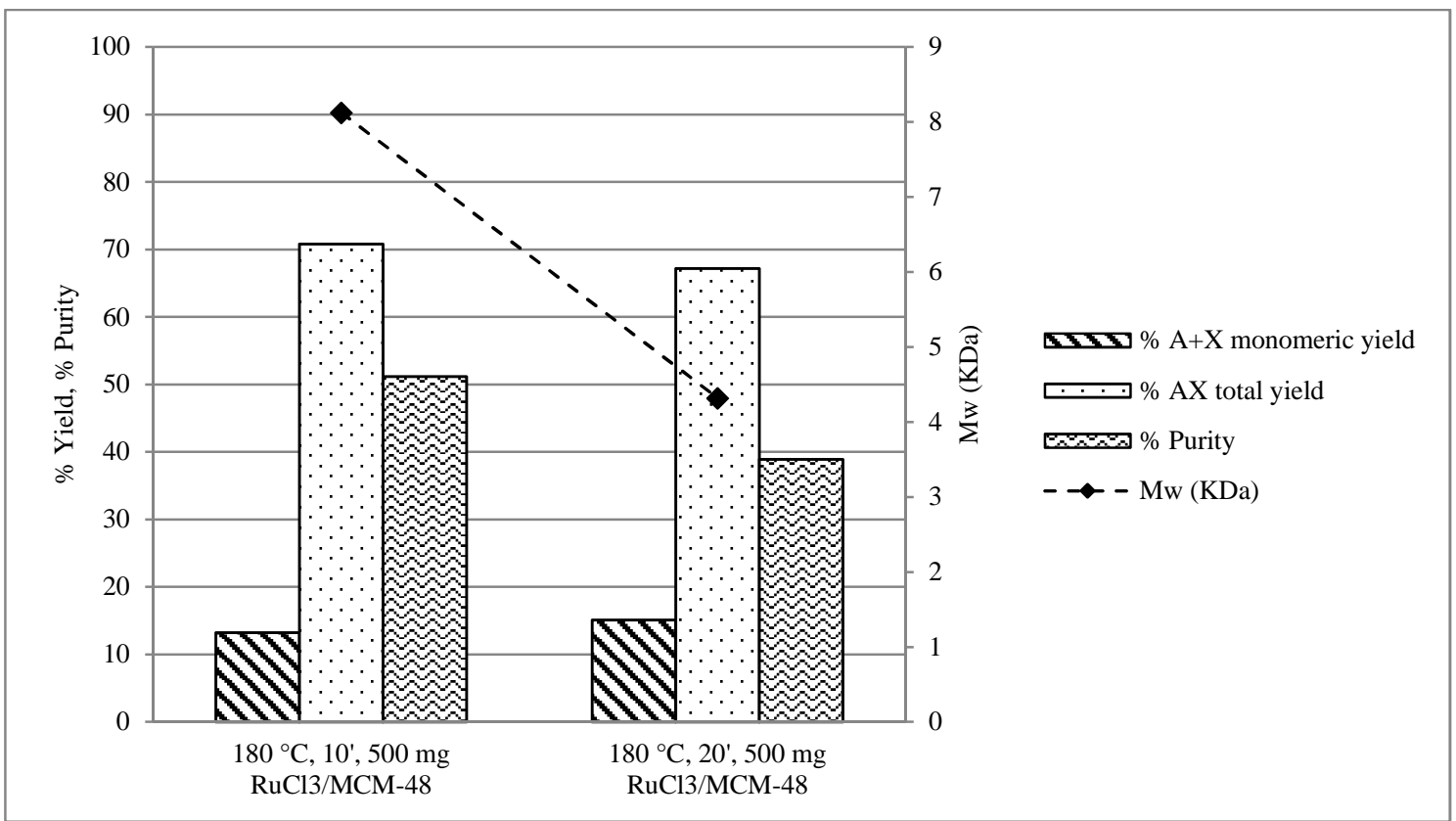

Figure 4. Effect of time on the AXs yield, purity and molecular weight of the liquid extract in the AXs extraction process. Extraction conditions: $4.8 \mathrm{~g}$ of destarched wheat bran, $160 \mathrm{~mL}$ of $\mathrm{H}_{2} \mathrm{O}, 500 \mathrm{mg} \mathrm{RuCl} 3 / \mathrm{MCM}-48$ (A: Arabinose, X: Xylose). 
Table 4. Effect of time on the yield of the different oligomer and total sugars obtained in the extraction process. Extraction conditions: $4.8 \mathrm{~g}$ of destarched wheat bran, $160 \mathrm{~mL}$ of $\mathrm{H}_{2} \mathrm{O}, 180$ ${ }^{\circ} \mathrm{C}, 500 \mathrm{mg} \mathrm{RuCl} 3 / \mathrm{MCM}-48$.

\begin{tabular}{|c|c|c|c|c|c|c|c|c|c|c|c|c|c|c|c|}
\hline \multicolumn{3}{|c|}{ Experimental conditions } & \multicolumn{6}{|c|}{ Yield as monomeric sugars ${ }^{\mathrm{a}}(\%)$} & \multicolumn{6}{|c|}{ Yield as total sugars ${ }^{\mathrm{b}}(\%)$} & \multirow[b]{2}{*}{$\mathrm{Ara} / \mathrm{Xyl}$} \\
\hline $\begin{array}{l}\mathrm{T} \\
\left({ }^{\circ} \mathrm{C}\right)\end{array}$ & $\begin{array}{l}\mathrm{t} \\
(\min )\end{array}$ & Catalyst (mg) & Glu & Xyl & Gal & Ara & Man & $\begin{array}{l}\mathrm{A}+\mathrm{X} \\
\text { yield }\end{array}$ & Glu & Xyl & Gal & Ara & Man & AX yield & \\
\hline 180 & 10 & $500 \mathrm{mg} \mathrm{RuCl} / \mathrm{MCM}-48$ & 2.9 & 3.0 & 10.2 & 32.8 & 14.4 & 13.3 & 28.2 & 70.6 & 46.9 & 71.2 & 14.7 & 70.8 & 0.53 \\
\hline 180 & 20 & $500 \mathrm{mg} \mathrm{RuCl} / \mathrm{MCM}-48$ & 3.6 & 5.7 & 12.5 & 33.1 & 11.5 & 15.1 & 35.1 & 71.7 & 48.3 & 58.6 & 16.4 & 67.2 & 0.43 \\
\hline & & $\begin{array}{l}\text { a Yield as monomeric s } \\
\text { b Yield as total sugars e } \\
{ }^{\mathrm{c}} \text { Ratio arabinose/xylos }\end{array}$ & $\begin{array}{l}\text { Jars ex } \\
\text { ractec } \\
\text { as tota }\end{array}$ & $\begin{array}{l}\text { racted } \\
\text { mono } \\
\text { sugars }\end{array}$ & $\begin{array}{l}\text { y origi } \\
\text { eric + }\end{array}$ & al sug & $\begin{array}{l}\text { i conte } \\
\text { ric) by }\end{array}$ & $\begin{array}{l}\text { nt in ra } \\
\text { origina }\end{array}$ & $\begin{array}{l}\text { rial } \\
\text { conte }\end{array}$ & in & mat & & & & \\
\hline
\end{tabular}

The influence of the catalyst support was studied in AXs extraction experiments from destarched wheat bran at $180{ }^{\circ} \mathrm{C}$ after 10 minutes (Figure 5). The amount of catalyst used was $500 \mathrm{mg}$ for $\mathrm{RuCl}_{3}$-based catalysts and $480 \mathrm{mg}$ for the mesoporous supports (480 $\mathrm{mg}$ is the amount of support contained in $500 \mathrm{mg}$ of $\mathrm{Ru}(4 \%)$-based catalysts). The tendency observed for the total AXs and the monosaccharides yield is as follows: MCM-48 < Al-MCM-48 < $\mathrm{Ru} / \mathrm{MCM}-48<\mathrm{Ru} / \mathrm{Al}-\mathrm{MCM}-48$. This is in agreement with the acidity values determined by acid-base titration: the higher the acidity, the higher amount of AXs solubilized. The acidity of MCM-48 comes from the terminal silanol groups $(\mathrm{Si}-\mathrm{OH})$ of the support. However, this kind of acidity corresponds to weak acid sites (Lewis acidity) (Xue et al., 2004), which is consistent with the yield results. Al-MCM-48 exhibits a better catalytic activity than MCM-48, what can be explained by the higher acidity of Al-MCM-48. During the synthesis of Al-MCM-48, an atom of silicon is substituted by an atom of aluminum in a tetrahedral structure. In this case, a cation, usually a proton, is needed to compensate the aluminum tetrahedron. This proton results in a Brønsted acid site, which is actually a strong acid site. Therefore, when the $\mathrm{Al} / \mathrm{Si}$ ratio increases, the number of strong acid sites is higher if all the cations are replaced by protons (Huang et al., 2008; Kao, Chang, Liao, Lee, \& Chien, 2008; Krithiga et al., 2005; Ribeiro Carrott et al., 2006). As mentioned before, the catalyst precursor $\left(\mathrm{RuCl}_{3}\right)$ used for the synthesis may the responsible for the high acidity of the $\mathrm{RuCl}_{3}$-based catalysts and therefore, for their better performance (Guisnet et al., 1993). 
The molecular weight of the liquid extract was higher using MCM-48 (26 KDa) and Al-MCM$48\left(20 \mathrm{KDa}\right.$ ) than the two corresponding $\mathrm{RuCl}_{3}$-based catalysts supported on them (around 8-9 $\mathrm{KDa}$ ), showing a major AXs hydrolysis when a more acid solid is incorporated to the extraction. Ruthenium catalysts not only improve the yield and help to hydrolyze the AXs into short oligomers but also lead to better results in terms of purity. Comparing the two ruthenium catalysts used in this work, $\mathrm{RuCl}_{3} / \mathrm{Al}-\mathrm{MCM}-48$ shows a better performance for the $\mathrm{AXs}$ extraction process from destarched wheat bran. With this catalyst, at $180{ }^{\circ} \mathrm{C}$ after 10 minutes, the total AXs yield was 78\%, the monosaccharides (arabinose + xylose) yield was $15 \%$, the purity was $54 \%$ and the molecular weight was $9 \mathrm{KDa}$. These results are comparable and in many cases better than those found in literature. A summary of the results obtained by several authors using different extraction method are shown in Table 5.

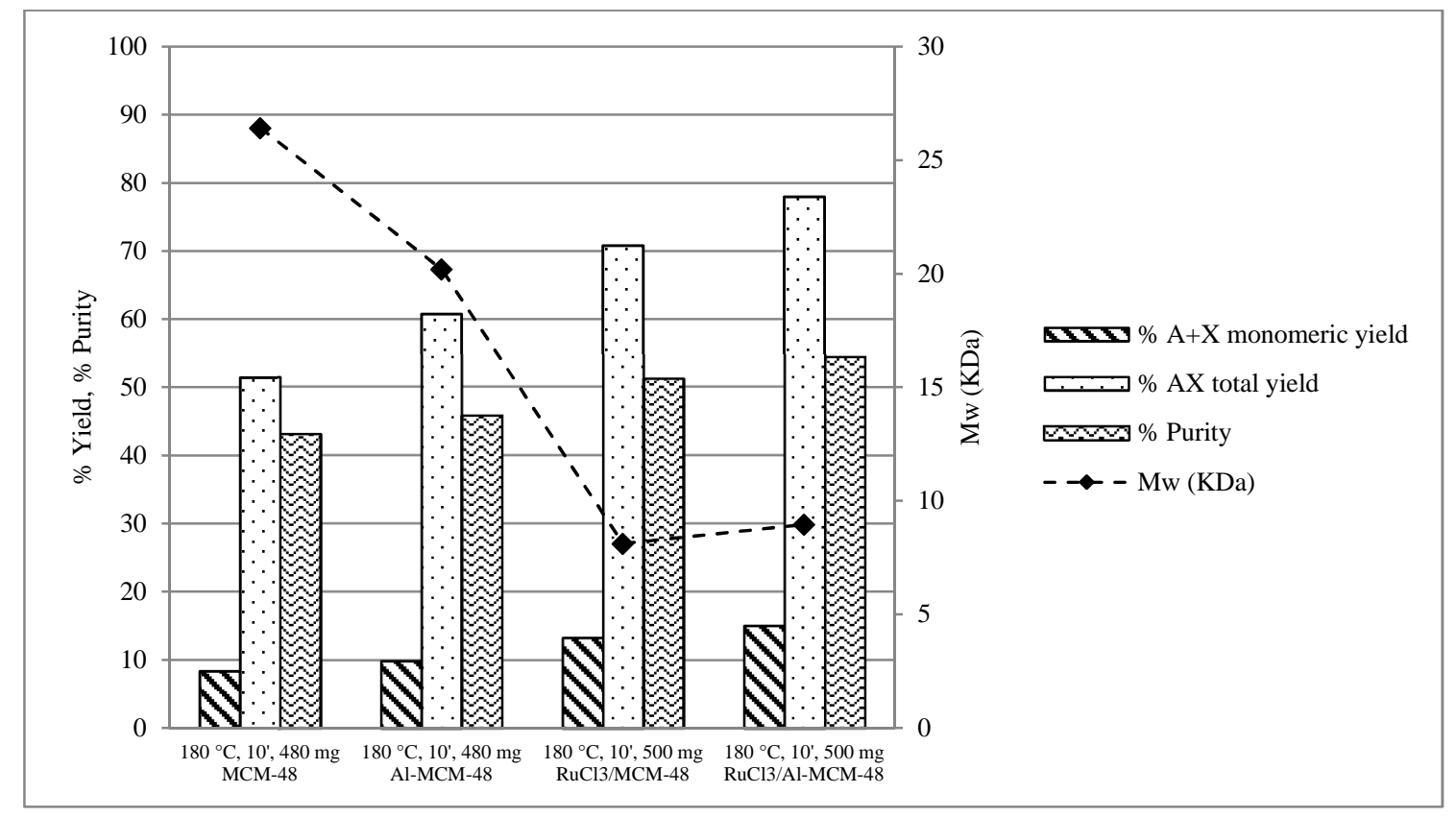

Figure 5. Effect of catalyst support on the AXs yield, purity and molecular weight of the liquid extract in the AXs extraction process. Extraction conditions: $4.8 \mathrm{~g}$ of destarched wheat bran, $160 \mathrm{~mL}$ of $\mathrm{H}_{2} \mathrm{O}, 180^{\circ} \mathrm{C}, 10$ minutes (A: Arabinose, $\mathrm{X}$ : Xylose). 
Table 5. Comparison of the results obtained in this work with the reported in literature by other extraction methods

\begin{tabular}{|c|c|c|c|c|}
\hline Extraction method & Raw material & Extraction conditions & AX yield $(\%)$ & Reference \\
\hline Hydrothermal & Destarched corn fiber & $\mathrm{H}_{2} \mathrm{O}, 180^{\circ} \mathrm{C}, 20 \mathrm{~min}$ & $71^{\mathrm{a}}$ & $\begin{array}{l}\text { (Dien et al., } \\
\text { 2006) }\end{array}$ \\
\hline Hydrothermal & Corncob & $\mathrm{H}_{2} \mathrm{O}, 190^{\circ} \mathrm{C}, 15 \mathrm{~min}$ & $58^{\mathrm{a}}$ & $\begin{array}{l}\text { (Nabarlatz et } \\
\text { al., 2004) }\end{array}$ \\
\hline Hydrothermal & Corncob & $\mathrm{H}_{2} \mathrm{O}, 175^{\circ} \mathrm{C}, 30 \mathrm{~min}$ & $69^{\mathrm{a}}$ & $\begin{array}{l}\text { (Garrote et } \\
\text { al., 2001) }\end{array}$ \\
\hline Hydrothermal & Corncob & $\mathrm{H}_{2} \mathrm{O}, 190^{\circ} \mathrm{C}, 12 \mathrm{~min}$ & $70^{\mathrm{a}}$ & $\begin{array}{l}\text { (Garrote et } \\
\text { al., 2001) }\end{array}$ \\
\hline Hydrothermal & Wheat bran & $\mathrm{H}_{2} \mathrm{O}, 180^{\circ} \mathrm{C}, 20 \mathrm{~min}$ & $70^{\mathrm{a}}$ & $\begin{array}{l}\text { (Reisinger et } \\
\text { al., 2013) }\end{array}$ \\
\hline Chemical & $\begin{array}{l}\text { Destarched wheat } \\
\text { bran }\end{array}$ & $0.44 \mathrm{M} \mathrm{NaOH}, 80^{\circ} \mathrm{C}, 15 \mathrm{~h}$ & $35^{\mathrm{a}}$ & $\begin{array}{l}\text { (Aguedo et } \\
\text { al., 2014) }\end{array}$ \\
\hline Chemical & $\begin{array}{l}\text { Destarched wheat } \\
\text { bran }\end{array}$ & $1 \mathrm{M} \mathrm{H}_{2} \mathrm{SO}_{4}, 180^{\circ} \mathrm{C}, 3 \mathrm{~min}$ & $32^{\mathrm{a}}$ & $\begin{array}{l}\text { (Aguedo et } \\
\text { al., 2014) }\end{array}$ \\
\hline Chemical & Destarched bran & $0.5 \mathrm{M} \mathrm{NaOH}, 40^{\circ} \mathrm{C}, 6 \mathrm{~h}$ & $16^{\mathrm{b}}$ & $\begin{array}{l}\text { (Bataillon et } \\
\text { al., 1998) }\end{array}$ \\
\hline Chemical & $\begin{array}{l}\text { Destarched wheat } \\
\text { bran }\end{array}$ & $0.16 \mathrm{M} \mathrm{NaOH}+\mathrm{H}_{2} \mathrm{O}_{2}$ & $21^{\mathrm{b}}$ & $\begin{array}{l}\text { (Zhang et al., } \\
\text { 2008) }\end{array}$ \\
\hline Chemical & Wheat bran & $2 \% \mathrm{H}_{2} \mathrm{O}_{2}, 40{ }^{\circ} \mathrm{C}, 6 \mathrm{~h}$ & $47^{\mathrm{a}}$ & $\begin{array}{l}\text { (Hollmann \& } \\
\text { Lindhauer, } \\
\text { 2005) }\end{array}$ \\
\hline Chemical & Destarched corn bran & $\begin{array}{l}30 \% \mathrm{H}_{2} \mathrm{O}_{2}+50 \% \mathrm{NaOH}, \text { Room } \\
\mathrm{T}, 2 \mathrm{~h}\end{array}$ & $31^{\mathrm{b}}$ & $\begin{array}{l}\text { (Doner et al., } \\
\text { 1998) }\end{array}$ \\
\hline Chemical & Barley husks & $\begin{array}{l}\mathrm{HCl} 0.05 \mathrm{M} \text { (pretreatment) + } \\
\mathrm{NaOH} 1 \mathrm{M} \text { (extraction), Room } \mathrm{T} \text {, } \\
16 \mathrm{~h}\end{array}$ & $26^{\mathrm{a}}$ & $\begin{array}{l}\text { (Höije et al., } \\
2005 \text { ) }\end{array}$ \\
\hline Enzymatic & $\begin{array}{l}\text { Destarched wheat } \\
\text { bran }\end{array}$ & Endoxylanase & $18^{\mathrm{b}}$ & $\begin{array}{l}\text { (Beaugrand et } \\
\text { al., 2004) }\end{array}$ \\
\hline Enzymatic & $\begin{array}{l}\text { Destarched wheat } \\
\text { bran }\end{array}$ & Endoxylanase, $24 \mathrm{~h}$ & $51^{\mathrm{a}}$ & $\begin{array}{l}\text { (Beaugrand et } \\
\text { al., 2004) }\end{array}$ \\
\hline Enzymatic & $\begin{array}{l}\text { Destarched wheat } \\
\text { bran }\end{array}$ & Xylanase, $60^{\circ} \mathrm{C}, 2 \mathrm{~h}$ & $12^{\mathrm{b}}$ & $\begin{array}{l}\text { (Zhou et al., } \\
2010)\end{array}$ \\
\hline Enzymatic & $\begin{array}{l}\text { Destarched wheat } \\
\text { bran }\end{array}$ & $\begin{array}{l}\text { Pentopan mono BG } 0.75 \%, 60^{\circ} \mathrm{C} \text {, } \\
3 \mathrm{~h}\end{array}$ & $15^{\mathrm{b}}$ & $\begin{array}{l}\text { (Zhang et al., } \\
\text { 2008) }\end{array}$ \\
\hline Enzymatic & Barley husks & $\alpha$ amyloglucosidase, $80^{\circ} \mathrm{C}, 1 \mathrm{~h}$ & $25^{\mathrm{a}}$ & $\begin{array}{l}\text { (Höije et al., } \\
\text { 2005) }\end{array}$ \\
\hline Enzymatic & $\begin{array}{l}\text { Destarched wheat } \\
\text { bran }\end{array}$ & Endoxylanase, $55^{\circ} \mathrm{C}, 24 \mathrm{~h}$ & $17^{\mathrm{a}}$ & $\begin{array}{l}\text { (Aguedo et } \\
\text { al., 2014) }\end{array}$ \\
\hline Enzymatic & Soissons & $\begin{array}{l}\text { Alcalase, Termamyl, } \\
\text { Amyloglucosidase, up to } 100^{\circ} \mathrm{C} \text {, } \\
\text { long times }\end{array}$ & $71^{\mathrm{a}}$ & $\begin{array}{l}\text { (Maes \& } \\
\text { Delcour. } \\
\text { 2002) }\end{array}$ \\
\hline Enzymatic & Thesée & $\begin{array}{l}\text { Alcalase, Termamyl, } \\
\text { Amyloglucosidase, up to } 100^{\circ} \mathrm{C} \text {, } \\
\text { long times }\end{array}$ & $75^{\mathrm{a}}$ & $\begin{array}{l}\text { (Maes \& } \\
\text { Delcour. } \\
\text { 2002) }\end{array}$ \\
\hline Enzymatic & Apollo & $\begin{array}{l}\text { Alcalase, Termamyl, } \\
\text { Amyloglucosidase, up to } 100{ }^{\circ} \mathrm{C} \text {, } \\
\text { long times }\end{array}$ & $91^{\mathrm{a}}$ & $\begin{array}{l}\text { (Maes \& } \\
\text { Delcour. } \\
\text { 2002) }\end{array}$ \\
\hline
\end{tabular}




\begin{tabular}{|c|c|c|c|c|}
\hline $\begin{array}{l}\text { Mechanical- } \\
\text { chemical }\end{array}$ & Destarched flax sives & $\mathrm{H}_{2} \mathrm{O}+$ microwave, $180^{\circ} \mathrm{C}, 10 \min$ & $18^{c}$ & $\begin{array}{l}\text { (Buranov \& } \\
\text { Mazza, 2010) }\end{array}$ \\
\hline $\begin{array}{l}\text { Mechanical- } \\
\text { chemical }\end{array}$ & Destarched flax sives & $\begin{array}{l}\mathrm{EtOH}+\text { microwave, } 180^{\circ} \mathrm{C}, 10 \\
\min \end{array}$ & $40^{c}$ & $\begin{array}{l}\text { (Buranov \& } \\
\text { Mazza, 2010) }\end{array}$ \\
\hline $\begin{array}{l}\text { Mechanical- } \\
\text { chemical }\end{array}$ & Wheat straw & $\begin{array}{l}0.5 \mathrm{M} \mathrm{KOH}+\text { ultrasounds, } 35^{\circ} \mathrm{C} \text {, } \\
30 \mathrm{~min}\end{array}$ & $25^{\mathrm{d}}$ & $\begin{array}{l}\text { (Sun \& } \\
\text { Tomkinson, } \\
\text { 2002) }\end{array}$ \\
\hline $\begin{array}{l}\text { Mechanical- } \\
\text { chemical }\end{array}$ & $\begin{array}{l}\text { Destarched wheat } \\
\text { bran }\end{array}$ & $\begin{array}{l}\text { Twin-screw extrusion (Clextral } \\
\text { BC45) combined with alkaline }\end{array}$ & $24^{\mathrm{d}}$ & $\begin{array}{l}\text { (Josefsson et } \\
\text { al., 2002) }\end{array}$ \\
\hline $\begin{array}{l}\text { Mechanical- } \\
\text { chemical }\end{array}$ & Wheat straw & $\begin{array}{l}\text { Steam explosion pre-treatment }+ \\
\mathrm{H}_{2} \mathrm{O}_{2}\end{array}$ & $33^{\mathrm{d}}$ & $\begin{array}{l}\text { (Sun et al., } \\
2005)\end{array}$ \\
\hline $\begin{array}{l}\text { Heterogeneous } \\
\text { catalysts }\end{array}$ & Bagasse & $\begin{array}{l}\mathrm{HBeta}(\mathrm{Si} / \mathrm{Al}=19), \mathrm{H}_{2} \mathrm{O}, 170^{\circ} \mathrm{C}, 1 \\
\text { h, } 50 \text { bar } \mathrm{N} 2\end{array}$ & $62^{\mathrm{a}}$ & $\begin{array}{l}\text { (Sahu \& } \\
\text { Dhepe, 2012) }\end{array}$ \\
\hline This work & $\begin{array}{l}\text { Destarched wheat } \\
\text { bran }\end{array}$ & $\begin{array}{l}500 \mathrm{mg} \mathrm{RuCl}{ }_{3} / \mathrm{Al}-\mathrm{MCM}-48, \mathrm{H}_{2} \mathrm{O} \\
180^{\circ} \mathrm{C}, 10 \mathrm{~min}\end{array}$ & $\begin{array}{l}78^{\mathrm{a}} \\
31^{\mathrm{b}} \\
67^{\mathrm{c}} \\
29^{\mathrm{d}}\end{array}$ & - \\
\hline
\end{tabular}

${ }^{a}$ Yield as total sugars extracted by original sugar content in raw material

${ }^{\mathrm{b}}$ Yield as total sugars extracted by initial raw material

${ }^{c}$ Yield as total hemicelluloses extracted by original hemicelluloses content in raw material

${ }^{\mathrm{d}}$ Yield as total hemicelluloses extracted by initial raw material

e) Relation between operating conditions, arabinoxylans yield and their molecular weight

Based on the results obtained, a relation between the different operating conditions, the arabinoxylans yield and the molecular weight was stablished (Table 6). Soft operating conditions (Exp. \#1, 2) correspond to a low AXs yield (12-13\%) with a low molecular weight (8-9 KDa). These conditions are $140{ }^{\circ} \mathrm{C}$ using $\mathrm{RuCl}_{3} / \mathrm{MCM}-48$ and $160{ }^{\circ} \mathrm{C}$, but without incorporating any catalyst, in both cases after 10 minutes. A low yield together with a low molecular weight means that only side chains of the AX structure are solubilized into water. However, when the operating conditions are moderate (Exp. \#3-5), it can be observed that the total AXs yield increases (24-35\%) and also the molecular weight (59-65 KDa). These results reflect the extraction of side chains and also part of the arabinoxylan backbone. The high molecular weight is because the AXs coming from the backbone are not still much hydrolyzed, since the experimental conditions are not strong enough to break them into smaller oligomers. More severe operating conditions (Exp. \#6-12) lead to a huge amount of AXs extracted (44$78 \%$ ) with a low molecular weight (4-26 KDa). In these cases, the AXs which constitute the backbone are not only solubilized but also hydrolyzed into shorter chain oligomers. Actually the experiment carried out at $180^{\circ} \mathrm{C}, 10$ minutes and using $\mathrm{RuCl}_{3} / \mathrm{Al}-\mathrm{MCM}-48$ gave the best results 
in terms of yield and molecular weight. Getting liquid extracts enriched in AXs with a low molecular weight makes them excellent raw materials to be used for further hydrogenation/oxidation reactions in which monomers or short oligomers are needed in order to obtain a high selectivity into sugar alcohols/furfural.

Table 6. Comparison of the different experiments in terms of experimental conditions, total AX yield and $\mathrm{Mw}$

\begin{tabular}{llll}
\hline \# Experiment & Experimental conditions & $\%$ AX total yield & Mw $(\mathrm{KDa})$ \\
\hline 1 & $140^{\circ} \mathrm{C}, 10^{\prime}, 500 \mathrm{mg} \mathrm{RuCl} / \mathrm{MCM}-48$ & 12 & 7.7 \\
2 & $160^{\circ} \mathrm{C}, 10^{\prime}$, no catalyst & 13 & 8.9 \\
3 & $160^{\circ} \mathrm{C}, 10^{\prime}, 480 \mathrm{mg} \mathrm{MCM}-48$ & 24 & 65.2 \\
4 & $160^{\circ} \mathrm{C}, 10^{\prime}, 500 \mathrm{mg} \mathrm{RuCl} / \mathrm{MCM}-48$ & 32 & 58.9 \\
5 & $160^{\circ} \mathrm{C}, 10^{\prime}, 500 \mathrm{mg} \mathrm{RuCl} / 3 / \mathrm{Al}-\mathrm{MCM}-48$ & 35 & 58.6 \\
6 & $160^{\circ} \mathrm{C}, 20^{\prime}, 500 \mathrm{mg} \mathrm{RuCl} / \mathrm{MCM}-48$ & 44 & 18.9 \\
7 & $160^{\circ} \mathrm{C}, 30^{\prime}, 500 \mathrm{mg} \mathrm{RuCl} / \mathrm{MCM}-48$ & 48 & 13.5 \\
8 & $180^{\circ} \mathrm{C}, 10^{\prime}, 0,4800 \mathrm{~g} \mathrm{MCM}^{-48}$ & 51 & 26.4 \\
9 & $180^{\circ} \mathrm{C}, 10^{\prime}, 0,4800 \mathrm{~g} \mathrm{Al}^{-M C M} 48$ & 61 & 20.2 \\
10 & $180^{\circ} \mathrm{C}, 20^{\prime}, 500 \mathrm{mg} \mathrm{RuCl} 3 / \mathrm{MCM}-48$ & 67 & 4.3 \\
11 & $180^{\circ} \mathrm{C}, 10^{\prime}, 500 \mathrm{mg} \mathrm{RuCl} / \mathrm{MCM}-48$ & 71 & 8.1 \\
12 & $180^{\circ} \mathrm{C}, 10^{\prime}, 500 \mathrm{mg} \mathrm{RuCl} / \mathrm{Al}-\mathrm{MCM}-48$ & 78 & 9.0 \\
\hline
\end{tabular}

\section{Conclusions}

In this work, a hydrothermal process assisted by heterogeneous catalysts has been successfully applied to recover the arabinoxylan fraction from destarched wheat bran. The addition of heterogeneous cataysts, based on mesoporous silica (MCM-48 type), enhances the hydrolysis rate in comparison with no catalyst experiments. The tendency observed for the total AXs and the monosaccharide yield is MCM-48 $<\mathrm{Al}-\mathrm{MCM}-48<\mathrm{RuCl}_{3} / \mathrm{MCM}-48<\mathrm{RuCl}_{3} / \mathrm{Al}-\mathrm{MCM}-48$ that corresponds to the tendency in the solid acidity. The extraction of high amounts of arabinoxylans with a low molecular weight is favored by relatively high temperatures, short extraction times and solid catalysts with high acidity. $\mathrm{RuCl}_{3}$-based catalysts were demonstrated to be more active in this process than the corresponding mesoporous silica supports. Optimum conditions were $180{ }^{\circ} \mathrm{C}, 10$ minutes and using $\mathrm{RuCl}_{3} / \mathrm{Al}-\mathrm{MCM}-48$ as catalyst. Under such 
conditions, the total arabinoxylans yield was $78 \%$ with a molecular weight around $9 \mathrm{KDa}$, what makes them suitable to be used for further hydrogenation/oxidation reactions.

\section{Acknowledgements}

This work was supported by the Spanish Government through the Research Project CTQ201564892-R (MINECO/FEDER). N. Sánchez-Bastardo thanks Ministerio de Educación Cultura y Deporte for financial support through a FPU predoctoral contract (FPU14/00812). A. Romero thanks to the program of predoctoral scholarships from Junta de Castilla y León Government for his grant (E-47-2015-0062773).

\section{References}

Adams, G. A. (1955). Constitution of a hemicellulose from wheat bran. Canadian Journal of Chemistry, 33, 56-67.

Aguedo, M., Fougnies, C., Dermience, M., \& Richel A. (2014). Extraction by three processes of arabinoxylans from wheat bran and characterization of the fractions obtained. Carbohydrate Polymers, 105, 317-324.

Aguedo, M., Vanderghem, C., Goffin, D., Richel, A., \& Paquot, M. (2013). Fast and high yield recovery of arabinose from destarched wheat bran. Industrial Crops and Products, 43, 318-325.

Amidon, T. E., \& Liu, S. (2009). Water-based woody biorefinery. Biotechnology Advances, 27, $542-550$.

Apprich, S., Tirpanalan, Ö., Hell, J., Reisinger, M., Böhmdorfer, S., Siebenhandl-Ehn, S., Novalin, S., \& Kneifel, W. (2014). Wheat bran-based biorefinery 2: Valorization of products. LWT - Food Science and Technology, 56, 222-231.

Bandura, A. V., \& Lvov, S. N. (2006). The ionization constant of water over wide ranges of temperature and density. Journal of Physical and Chemical Reference Data, 35, 14-30. 
Bataillon, M., Mathaly, P., Nunes Cardinali, A-P., \& Duchiron, F. (1998). Extraction and purification of arabinoxylan from destarched wheat bran in a pilot scale. Industrial Crops and Products, 8, 37-43.

Beaugrand, J., Chambat, G., Wong, V. W. K, Goubet, F., Rémond, C., Paës, G., Benamrouche, S., Debeire, P., O’Donohue, M., \& Chabbert, B. (2004). Impact and efficiency of GH10 and GH11 thermostable endoxylanases on wheat bran and alkali-extractable arabinoxylans. Carbohydrate Research, 339, 2529-2540.

Beaugrand, J., Crônier, D., Debeire, P., \& Chabbert, B. (2004). Arabinoxylan and hydroxycinnamate content of wheat bran in relation to endoxylanase susceptibility. Journal of Cereal Science, 40, 223-230.

Benito-Román, Ó., Alonso, E., Gairola, K., \& Cocero, M. J. (2013). Fixed-bed extraction of $\beta$ glucan from cereals by means of pressurized hot water. The Journal of Supercritical Fluids, 82, $122-128$.

Benito-Román, Ó., Alonso, E., Palacio, L., Prádanos, P., \& Cocero, M. J. (2014). Purification and isolation of $\beta$-glucans from barley: Downstream process intensification. Chemical Engineering and Processing: Process Intensification, 84, 90-97.

Bobleter, O. (1994). Hydrothermal degradation of polymers derived from plants. Progress in Polymer Science, 19, 797-841.

Buranov, A. U., \& Mazza, G. (2010). Extraction and characterization of hemicelluloses from flax shives by different methods. Carbohydrate Polymers, 79, 17-25.

Carvalheiro, F., Garrote, G., Parajó, J. C., Pereira, H., \& Gírio, F. M. (2005). Kinetic modeling of brewery's spent grain autohydrolysis. Biotechnology Progress, 21, 233-243.

Choteborská, P., Palmarola-Adrados, B., Galbe, M., Zacchi, G., Melzoch, K., \& Rychtera, M. (2004). Processing of wheat bran to sugar solution. Journal of Food Engineering, 61, 561-565. 
Das, A. M., Hazarika, M. P., Goswami, M., Yadav, A., \& Khound, P. (2016). Extraction of cellulose from agricultural waste using Montmorillonite $\mathrm{K}-10 / \mathrm{LiOH}$ and its conversion to renewable energy: Biofuel by using Myrothecium gramineum. Carbohydrate Polymers, 141, $20-27$.

De Almedia, R. M., De Albuquerque, N. J. A., Souza, F. T. C., \& Meneghetti, S. M. P. (2016). Catalysts based on $\mathrm{TiO}_{2}$ anchored with $\mathrm{MoO}_{3}$ or $\mathrm{SO}_{4}{ }^{2-}$ for conversion of cellulose into chemicals. Catalysis Science \& Technology, 6, 3137-3142.

Dervilly-Pinel, G., Rimsten, L., Saulnier, L., Andersson, R., \& Aman, P. (2001). Waterextractable arabinoxylan from pearled flours of wheat, barley, rye and triticale. Evidence for the presence of ferulic acid dimers and their involvement in gel formation. Journal of Cereal Science, 34, 207-214.

Dien, B. S., Li, X-L., Iten, L. B., Jordan, D. B., Nichols, N. N., O’Bryan, P. J., \& Cotta, M. A. (2006). Enzymatic saccharification of hot-water pretreated corn fiber for production of monosaccharides. Enzyme and Microbial Technology, 39, 1137-1144.

Doner, L. W., Chau, H. K., Fishman, M. L., \& Hicks, K. B. (1998). An improved process for isolation of corn fiber gum. Cereal Chemistry, 75, 408-411.

Ebringerova, Z., Hromadkova, J. H., Alfoldi, J., \& Ibalova, V. (1998). The immunologically active xylan from ultrasound-treated corn cobs: Extractability, structure and properties. Carbohydrate Polymers, 37, 231-239.

Faba, L., Kusema, B. T., Murzina, E. V., Tokarev, A., Kumar, N., Smeds, A., Díaz, E., Ordóñez, S., Mäki-Arvela, P., Willför, S., Salmi, T., \& Murzin, D. Y. (2014). Hemicellulose hydrolysis and hydrolytic hydrogenation over proton- and metal modified beta zeolites. Microporous and Mesoporous Materials, 189, 189-199. 
Faurot, A-L., Saulnier, L., Bérot, S., Popineau, Y., Petit, M-D., Rouau, X., \& Thibault, J-F. (1995). Large scale isolation of water-soluble and water-insoluble pentosans from wheat flour. LWT - Food Science and Technology, 28, 436-441.

Fukushima, R. S., \& Hatfield, D. (2004). Comparison of the acetyl bromide spectrophotometric method with other analytical lignin methods for determining lignin concentration in forage samples. Journal of Agricultural and Food Chemistry, 52, 3713-3720.

Ganguli, N. K., \& Turner, M. A. (2008). A simplified method for extracting water-extractable arabinoxylans from wheat flour. Journal of the Science of Food and Agriculture, 88, 1905-1910.

Garrote, G., Domínguez, H., \& Parajó, J. C. (2002). Autohydrolysis of corncob: study of nonisothermal operation for xylooligosaccharide production. Journal of Food Engineering, 52, 211-218.

Garrote, G., Domínguez, H., \& Parajó, J. C. (1999). Hydrothermal processing of lignocellulosic materials. Holz als Roh - und Werkstoff, 57, 191-202.

Garrote, G., Domínguez, H., \& Parajó, J. C. (2001). Kinetic modelling of corncob autohydrolysis. Process Biochemistry, 36, 571-578.

Geboers, J. A., Van de Vyver, S., Ooms, R., Op de Beeck, B., Jacobs, P. A., \& Sels, B. F. (2011). Chemocatalytic conversion of cellulose: opportunities, advances and pitfalls. Catalysis Science \& Technology, 1, 714-726.

Gebruers, K., Dornez, E., Boros, D., Frás, A., Dynkowska, W., Bedo, Z., Rakszegi, M., Delcour, J. A., \& Courtin, C. M. (2008). Variation in the content of dietary fiber and components thereof in wheats in the HEALTHGRAIN diversity screen. Journal of Agricultural and Food Chemistry, 56, 9740-9749. 
Guisnet, M., Barbier, J., Barrault, J., Bouchoule, C., Duprez, D., Pérot, G., \& Montassier, C. (1993). Studies in Surface Science and Catalysis. Heterogeneous Catalysis and Fine Chemicals III. ( $1^{\text {st }}$ ed). Poitiers: Elsevier Science.

Hames, B., Scarlata, C., \& Sluiter, A. (May 2008). Determination of Protein Content in Biomass. Laboratory Analytical Procedure (LAP). Technical Report NREL/TP-510-42625.

Hara, M. (2010). Biomass conversion by a solid acid catalyst. Energy and Environmental Science, 3, 601-607.

Höije, A., Gröndahl, M., Tømmeraas, K., \& Gatenholm, P. (2005). Isolation and characterization of physicochemical and material properties of arabinoxylans from barley husks. Carbohydrate Polymers, 61, 266-275.

Hollmann, J., \& Lindhauer, M. G. (2005). Pilot-scale isolation of glucuronoarabinoxylans from wheat bran. Carbohydrate Polymers, 59, 225-230.

Hu, H., Li, Z., Wu, Z., Lin, L., \& Zhou, S. (2016). Catalytic hydrolysis of microcrystalline and rice straw-derived cellulose over a chlorine-doped magnetic carbonaceous solid acid. Industrial Crops and Products, 84, 408-417.

Hu, L., Tang, X., Wu, Z., Lin, L., Xu, J., Xu, N., \& Dai, B. (2015). Magnetic lignin-derived carbonaceous catalyst for the dehydration of fructose into 5-hydroxymethylfurfural in dimethylsulfoxide. Chemical Engineering Journal, 263, 299-308.

Huang, J., Jiang, Y., Reddy Marthala, V. R., Thomas, B., Romanova, E., \& Hunger, M. (2008). Characterization and Acidic Properties of Aluminum-Exchanged Zeolites X and Y. Journal of Physical Chemistry C, 112, 3811-3818.

Huang, Y-B., \& Fu, Y. (2013). Hydrolysis of cellulose to glucose by solid acid catalysts. Green Chemistry, 15, 1095-1111. 
Izydorczyk, M. S., \& Biliaderis, C. G. (2007). Arabinoxylans: Technologically and nutritionally functional plant polysaccharides. In C.G. Biliaderis, and M.S. Izydorczyk (Eds.), Functional food carbohydrates, 249-290. Boca Raton: CRC Press.

Jacquemin, L., Zeitouna, R., Sablayrolles, C., Pontalier, P. Y., \& Rigal, L. (2012). Evaluation of the technical and environmental performances of extraction and purification processes of arabinoxylans from wheat straw and bran. Process Biochemistry, 47, 373-380.

Josefsson, T., Lennholm, H., \& Gellerstedt, G. (2002). Steam explosion of Aspen Wood. Characterisation of reaction products. Holzforschung, 56, 289-297.

Kao, H-M., Chang, P-C., Liao, Y-W., Lee, L-P., \& Chien, C-H. (2008). Solid-state NMR characterization of the acid sites in cubic mesoporous Al-MCM-48 materials using trimethylphosphine oxide as a P NMR probe. Microporous and Mesoporous Materials, 114, $352-364$

Kim, Y., Hendrickson, R., Mosier, N. S., \& Ladisch, M. R. (2009). Liquid hot pretreatment of cellulosic biomass. Methods in molecular biology (Clifton, N.J.), 581, 93-102.

Kim, Y., Kreke, T., \& Ladisch, M. R. (2013). Reaction mechanisms and kinetics of xylo-oligosaccharide hydrolysis by dicarboxylic acids. AlChe Journal, 59, 188-199.

Kobayashi, H., Tasuku Komanoya, T., Guha, S. K., Hara, K., \& Fukuoka, A. (2011). Conversion of cellulose into renewable chemicals by supported metal catalysis. Applied Catalysis A: General, 409-410, 13-20.

Krithiga, T., Vinu, A., Ariga, K., Arabindoo, B., Palanichamy, M., \& Murugesan, V. (2005). Selective formation 2,6-diisopropyl naphthalene over mesoporous Al-MCM-48 catalysts. Journal of Molecular Catalysis A: Chemical, 237, 238-245. 
Kusema, B. T, Hilmann, G., Mäki-Arvela, P., Willför, S., Holmbom, B., Salmi, T., \& Murzin, D. Y. (2011). Selective hydrolysis of arabinogalactan into arabinose and galactose over heterogeneous catalysts. Catalysis Letters, 141, 408-412,

Kusema, B. T., Faba, L., Kumar, N., Mäki-Arvela, P., Díaz, E., Ordóñez, S., Salmi, T., \& Murzin, D. Y. (2012). Hydrolytic hydrogenation of hemicellulose over metal modified mesoporous catalyst. Catalysis Today, 196, 26-33.

Lavarack, B. P., Griffin, G. J., \& Rodman, D. (2000). Measured kinetics of the acid-catalysed hydrolysis of sugar cane bagasse to produce xylose. Catalysis Today, 63, 257-265.

Lavarack, B. P., Griffin, G. J., and Rodman, D. (2002). The acid hydrolysis of sugarcane bagasse hemicellulose to produce xylose, arabinose, glucose and other products. Biomass \& Bioenergy, 23, 367-380.

Li, X., Converse, A. O., \& Wyman, C. E. (2003). Characterization of molecular weight distribution oligomers from autocatalyzed batch hydrolysis of xylan. Applied Biochemistry and Biotechnology - Part A Enzyme Engineering and Biotechnology, 107, 515-522.

Liu, W-J., Tian, K., Jiang, H., \& Yu, H-Q. (2013). Facile synthesis of highly efficient and recyclable magnetic solid acid from biomass waste. Scientific Reports, 3, 2419.

Maes, C. \& Delcour, J. A. (2002). Structural of water-extractable and water-unextractable arabinoxylans in wheat bran. Journal of Cereal Science, 35, 315-326.

Mishra, D. K., Dabbawala, A. A., \& Hwang, J-S. (2013). Ruthenium nanoparticles supported on zeolite $\mathrm{Y}$ as an efficient catalyst for selective hydrogenation of xylose to xylitol. Journal of Molecular Catalysis A: Chemical, 376, 63-70.

Mok, W.S-L., \& Antal, M. J., Jr. (1992). Uncatalyzed solvolysis of whole biomass hemicellulose by hot compressed liquid water. Industrial and Engineering Chemistry Research, $31,1157-1161$. 
Morais, A. R. C, Matuchaki, M. D. D. J., Andreaus, J., \& Bogel-Lukasik, R. (2016). A green and efficient approach to selective conversion of xylose and biomass hemicellulose into furfural in aqueous media using high-pressure $\mathrm{CO}_{2}$ as a sustainable catalyst. Green Chemistry, 18, 29852994.

Murzin, D. Y., Murzina, E. V., Tokarev, A., Shcherban, N. D., Wärnå, J., \& Salmi, T. (2015). Arabinogalactan hydrolysis and hydrolytic hydrogenation using functionalized carbon materials. Catalysis Today, 257, 169-176.

Nabarlatz, D., Farriol, X., \& Montané, D. (2004). Kinetic modeling of the autohydrolysis of lignocellulosic biomass for the production of hemicellulose-derived oligosaccharides. Industrial and Engineering Chemistry Research, 43, 4124-4131.

Nandini, C. D., \& Salimath, P. V. (2001). Carbohydrate composition of wheat, wheat bran, sorghum and bajra with good chapati/roti (Indian flat bread) making quality. Food Chemistry, 73, 197-203.

Negahdar, L., Delidovich, I., \& Palkovits, R. (2016). Aqueous-phase hydrolysis of cellulose and hemicelluloses over molecular acidic catalysts: Insights into the kinetics and reaction mechanism. Applied Catalysis B: Environmental, 184, 285-298.

Ogawa, K., Takeuchi, M., \& Nakamura, N. (2005). Immunological effects of partially hydrolyzed arabinoxylan from corn husk in mice. Bioscience, Biotechnology and Biochemistry, 69, 19-25.

Ordaz-Ortiz, J. J., \& Saulnier, L. (2005). Structural variability of arabinoxylans from wheat flour. Comparison of water-extractable and xylanase-extractable arabinoxylans. Journal of Cereal Science, 42, 119-125. 
Prückler, M., Siebenhandl-Ehn, S., Apprich, S., Höltinger, S., Haas, C., Schmid, E., \& Kneifel, W. (2014). Wheat bran-based biorefinery 1: Composition of wheat bran and strategies of functionalization. LWT - Food Science and Technology, 56, 211-221.

Reisinger, M., Tirpanalan, Ö., Prückler, M., Huber, F., Kneifel, W., \& Novalin, S. (2013). Wheat bran biorefinery - A detailed investigation on hydrothermal and enzymatic treatment. Bioresource Technology, 144, 179-185.

Ribeiro Carrott, M. M. L., Conceição, F. L., Lopes, J. M., Carrott, P. J. M., Bernardes, C., Rocha, J., \& Ramôa Ribeiro, F. (2006). Comparative study of Al-MCM materials prepared at room temperature with different aluminium sources and by some hydrothermal methods. Microporous and Mesoporous Materials, 92, 270-285.

Romero, A., Alonso, E., Sastre, Á., \& Nieto-Márquez, A. (2016). Conversion of biomass into sorbitol: cellulose hydrolysis on MCM-48 and D-glucose hydrogenation on Ru/MCM-48. Microporous \& Mesoporous Materials, 224, 1-8.

Rose, D. J., \& Inglett, G. E. (2010). Production of feruloylated arabinoxylo-oligosaccharides from maize (Zea mays) bran by microwave-assisted autohydrolysis. Food Chemistry, 119, $1613-1618$.

Sahu, R., \& Dhepe, P. L. (2012). A one-pot method for the selective conversion of hemicellulose from crop waste into C5 sugars and furfural by using solid acid catalysts. ChemSusChem, 5, 751-761.

Salmi, T., Murzin, D. Y., Mäki-Arvela, P., Kusema, B., Holmbom, B., Willför, S., \& Wärna, J. (2014). Kinetic modeling of hemicellulose hydrolysis in the presence of homogeneous and heterogeneous catalysts. AlChE Journal, 60, 1006-1077.

Seyer, M-É., \& Gélinas, P. (2009). Bran characteristics and wheat performance in whole wheat bread. International Journal of Food Science \& Technology, 44, 688-693. 
Shen, J., \& Wyman, C. E. (2011). A novel mechanism and kinetic model to explain enhanced xylose yields from dilute sulfuric acid compared to hydrothermal pretreatment of corn stover. Bioresource Technology, 102, 9111-9120.

Sifontes Herrera, V. A., Saleem, F., Kusema, B., Eränen, K., \& Salmi, T. (2012). Hydrogenation of L-Arabinose and D-Galactose mixtures over a heterogeneous $\mathrm{Ru} / \mathrm{C}$ catalyst. Topics in Catalysis, 55, 550-555.

Sluiter, A., Hames, B., Ruiz, R., Scarlata, C., Sluiter, J., \& Templeton, D. (January 2008). Determination of Sugars, Byproducts, and Degradation Products in Liquid Fraction Process Samples. Laboratory Analytical Procedure (LAP). Technical Report NREL/TP-510-42623.

Sluiter, J., \& Sluiter, A. (Revised July 2011). Summative Mass Closure. Laboratory Analytical Procedure (LAP). Review and Integration. Technical Report NREL/TP-510-48087.

Sun, R. C., \& Tomkinson, J. (2002). Characterization of hemicelluloses obtained by classical and ultrasonically assisted extractions from wheat straw. Carbohydrate Polymers, 50, 263-271.

Sun, X. F., Xu, F., Sun, R. C., Geng, Z. C., Fowler, P., \& Baird, M. S. (2005). Characteristics of degraded hemicellulosic polymers obtained from steam exploded wheat straw. Carbohydrate Polymers, 60, 15-26.

Swennen, K., Courtin, C. M., Lindemans, G.CJE., \& Delcour, J. A. (2006). Large-scale production and characterisation of wheat bran arabinoxylooligosaccharides. Journal of the Science of Food and Agriculture, 86, 1722-1731.

Tathod, A., Kane, T., Sanil, E. S., \& Dhepe, P. L. (2014). Solid base supported metal catalysts for the oxidation and hydrogenation of sugars. Journal of Molecular Catalysis A: Chemical, 388-389, 90-99.

Tathod, A. P., \& Dhepe, P. L. (2015). Efficient method for the conversion of agricultural waste into sugar alcohols over supported bimetallic catalysts. Bioresource Technology, 178, 36-44. 
Tekin, K., Karagöz, S., \& Bektaş, S. (2014). A review of hydrothermal biomass processing. Renewable and Sustainable Energy Reviews, 40, 673-687.

Tirpanalan, Ö., Reisinger, M., Huber, F., Kneifel, W., \& Novalin, S. (2014). Wheat bran biorefinery: An investigation on the starch derived glucose extraction accompanied by pre- and post-treatment steps. Bioresource Technology, 163, 295-299.

Van de Vyver, S., Geboers, J., Peng, L., de Clippel, F., Dusselier, M., Vosch, T., Zhang, L., Van Tendeloo, G., Gommes, C. J., Goderis, B., Jacobs, P. A., \& Sels, B. F. (2011). Bridging the gap between cellulose chemistry and heterogeneous catalysis. WIT Transactions on Ecology and the Environment, 154, 129-140.

Wang, J., Xu, W., Ren, J., Liu, X., Lu, G., \& Wang, Y. (2011). Efficient catalytic conversion of fructose into hydroxymethylfurfural by a novel carbon-based solid acid. Green Chemistry, 13, $2678-2681$.

Xu, F., Liu, C. F., Geng, Z. C., Sun, J. X., Sun, R. C., Hei, B. H., Lin, L., Wu, S. B., \& Je, J. (2006). Characterisation of degraded organosolv hemicelluloses from wheat straw. Polymer Degradation and Stability, 91, 1880-1886.

Xue, P., Lu, G., Guo, Y., Wang, Y., \& Guo, Y. (2004). A novel support of MCM-48 molecular sieve for immobilization of penicillin G acylase. Journal of Molecular Catalysis B: Enzymatic, $30,75-81$.

Yadav, M., Mishra, D. K., \& Hwang, J-S. (2012). Catalytic hydrogenation of xylose to xylitol using ruthenium catalyst on $\mathrm{NiO}$ modified $\mathrm{TiO}_{2}$ support. Applied Catalysis A: General, 425 $426,110-116$.

Yao, S., Nie, S., Yuan, Y., Wang, S., \& Qin, C. (2015). Efficient extraction of bagasse hemicelluloses and characterization of solid remainder. Bioresource Technology, 185, 21-27. 
Yoshida, T., Tsubaki, S., Teramoto, Y., \& Azuma, J. (2010). Optimization of microwave assisted extraction of carbohydrates from industrial waste of corn starch production using response surface methodology. Bioresource Technology, 101, 7820-7826.

Zeitoun, R., Pontalier, P. Y., Marechal, \& P., Rigal, L. (2010). Twin-screw extrusion for hemicellulose recovery: Influence on extract purity and purification performance. Bioresource Technology, 101, 9348-9354.

Zhang, X., Wang, S., Zhou, S., \& Fu, X. (2008). Optimization of alkaline extraction conditions for arabinoxylan from wheat bran. Journal of Nuclear Agricultural Sciences, 22, 60-64.

Zhang, X., Zhou, S., \& Wang, S. (2008). Optimizing enzymatic hydrolysis conditions of arabinoxylan in wheat bran through quadratic orthogonal rotation combination design. Food Science, $28,141-145$.

Zhang, Z., Smith, C., \& Li, W. (2014). Extraction and modification technology of arabinoxylans from cereal by-products: A critical review. LWT - Food Science and Technology, 65, 423-436.

Zheng, F-C., Chen, Q-W., Hu, L., Yan, N., \& Kong, X-K. Synthesis of sulfonic acidfunctionalized $\mathrm{Fe}_{3} \mathrm{O}_{4} @ \mathrm{C}$ nanoparticles as magnetically recyclable solid acid catalysts for acetalization reaction. Dalton Transactions, 43, 1220-1227.

Zhou, S., Liu, X., Guo, Y., Wang, Q., Peng, D., \& Cao, L. (2010). Comparison of the immunological activities of arabinoxylans from wheat bran with alkali and xylanase-aided extraction. Carbohydrate Polymers, 81, 784-789. 